\title{
2020 Year in Review: Mechanical Ventilation During the First Year of the COVID-19 Pandemic
}

\author{
Richard H Kallet
}

\author{
Introduction \\ To Intubate or Not? \\ Is This Really ARDS? \\ The Theory of ARDS Phenotypes \\ COVID-19 Phenotypes \\ COVID-19 Phenotypes and LPV \\ Phenotypes Versus Disease Evolution in COVID-19 \\ Conflicting Evidence Regarding COVID-19 Phenotypes \\ Pathologic and Radiologic Features of COVID-19 \\ Renin-Angiotensin System and Hypoxemia in COVID-19 \\ Observation and Interpretation During a Global Medical Crisis \\ The Theory of Patient Self-Inflicted Lung Injury \\ Invasive Ventilation Usage and Associated Mortality \\ Invasive Ventilation Duration \\ PEEP and $V_{T}$ Parameters \\ Respiratory System Compliance \\ Lung and Chest Wall Compliance \\ Interplay of Oxygenation, PEEP, and Compliance \\ Lung Recruitment Potential \\ Role of NIV in ARDS and Viral-Induced ARDS \\ Role of NIV in COVID-19 \\ Risk of Health Care Provider Cross-Infection During NIV \\ Summary
}

Coronavirus disease 2019 (COVID-19) represents the greatest medical crisis encountered in the young history of critical care and respiratory care. During the early months of the pandemic, when little was known about the virus, the acute hypoxemic respiratory failure it caused did not appear to fit conveniently or consistently into our classification of ARDS. This not only reignited a half-century's long simmering debate over taxonomy, but also fueled similar debates over how PEEP and lung-protective ventilation should be titrated, as well as the appropriate role of noninvasive ventilation in ARDS. COVID-19 ignited other debates on emerging concepts such as ARDS phenotypes and patient self-inflicted lung injury from vigorous spontaneous breathing. Over a year later, these early perplexities have receded into the background without having been reviewed or resolved. With a full year of evidence having been published, this narrative review systematically analyzes whether COVID-19-associated respiratory failure is essentially ARDS, with perhaps a somewhat different course of presentation. This includes a review of the severity of hypoxemia and derangements in pulmonary mechanics, PEEP requirements, recruitment potential, ability to achieve lung-protective ventilation goals, duration of mechanical ventilation, associated mortality, and response to noninvasive ventilation. This paper also reviews the concepts of ARDS phenotypes and patient self-inflicted lung injury as these are crucial to 


\section{Mechanical Ventilation During the First Year of COVID-19}

understanding the contentious debate over the nature and management of COVID-19. Key words: acute respiratory distress syndrome; coronavirus disease 2019; lung-protective ventilation; noninvasive ventilation; patient self-inflicted lung injury. [Respir Care 2021;66(8):1341-1362. (C) 2021 Daedalus Enterprises]

\section{Introduction}

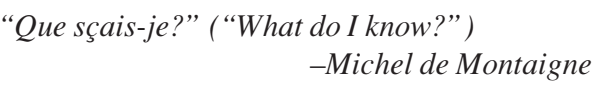

With the exception of acquired immunodeficiency syndrome (AIDS), coronavirus disease 2019 (COVID-19) represents the greatest medical crisis the world has confronted since the "Great Influenza" pandemic of 1918. And certainly it is the most profound crisis in the young history of critical care and respiratory care. Even the AIDS epidemic did not remotely resemble the enormous strain on critical care capacity, health care provider staffing, and mechanical ventilators. However, this review of mechanical ventilation during the first year of the pandemic is not concerned with issues that captivated both mainstream and social media, such as the lack of ventilators. Rather its focus is the more interesting and deeper issue that animated the first months of pandemic and lingers still, perhaps forgotten or dismissed by many, but nonetheless one without definitive resolution or consensus.

At the pandemic's onset there seemed to be a collective moment of self-doubt amid the terrifying chaos of COVID19. Its apparently unusual presentation questioned how we apply the term ARDS and its ramifications on our approach to treatment. This uncertainty vaguely resembled controversies from the 1970s when the very idea of ARDS was considered by some "a distinctive non-entity" that "serves no useful purposes." This is not to insinuate that in 2020 the validity of ARDS as an entity was being challenged, but rather the validity of what is encompassed by the definition. The specific characteristics of ARDS presentation have always engendered debate. The pandemic simply brought these long simmering issues to the forefront again. The

\footnotetext{
Mr Kallet is affiliated with the Department of Anesthesia and Perioperative Care, University of California, San Francisco at Zuckerberg San Francisco General Hospital and Trauma Center, San Francisco, California.
}

A version of this paper was presented at AARC Congress 2020 LIVE! held virtually, December 5, 2020.

Supplementary material related to this paper is available at http://www. rcjournal.com.

Mr Kallet has disclosed relationships with Nihon Kohden and ContinuED.

Correspondence: Richard H Kallet MSc RRT FAARC, 2070 Fell St \#1, San Francisco, CA 94117. E-mail: richkallet@gmail.com.

DOI: $10.4187 /$ respcare.09257 basis for this was established in 2003 when the term "severe acute respiratory syndrome" (SARS) was coined rather than an alternative name in which ARDS was a salient feature. ${ }^{2}$ Naming has consequences.

Now with the perspective of time, the accruement of experience, data, and waning emotions, this narrative review is focused on our current understanding of COVID-19associated respiratory failure and its response to mechanical ventilation. It also explores the controversies that arose in the early months of the pandemic. During this time frame, interesting opinions regarding both ARDS and COVID-19 were expressed, most based upon clinical impressions and interpretation of the scientific literature that deserve further exploration. These topics are consigned to supplementary materials for those interested (see the supplementary materials at http://www.rcjournal.com). For the primary topics of interest, the critique presented in this review focuses on how COVID-19 resembles or differs from our current understanding of ARDS. The intention is that we might answer the question the great Renaissance philosopher Michel de Montaigne posed to himself every day: What do I know? ${ }^{3}$

\section{To Intubate or Not?}

Two inter-related clinical management controversies arose almost immediately after the pandemic reached Europe and the United States. The first was whether patients with respiratory insufficiency should be intubated before exhibiting signs of overt failure. ${ }^{4,5}$ The second was whether an apparently unusual presentation of COVID-19 respiratory failure was indeed ARDS, thereby raising questions whether the approach to invasive ventilation should be modified in response. ${ }^{6-8}$ These controversies influenced how respiratory care was practiced over the first year of the pandemic.

The rationale for early invasive ventilation was based upon 3 factors. First, fear regarding potential aerosolization due to managing patients either with noninvasive invasive ventilation (NIV) or high-flow nasal oxygen. ${ }^{9-11}$ Clinicians involved with aerosol-generating procedures have $\sim 3$ times the infection risk compared to other health care professionals. ${ }^{12}$ Early on, the infection rate among health care workers was $\sim 4 \%$ in China (the majority in Wuhan) and $14 \%$ in Italy. ${ }^{13,14}$ Second was a concern for the potential development of patient self-inflicted lung injury caused by spontaneous breathing at a supranormal tidal volume $\left(\mathrm{V}_{\mathrm{T}}\right)$ generated by high transalveolar pressures $\left(>-15 \mathrm{~cm} \mathrm{H}_{2} \mathrm{O}\right)$ 
from a combination of high respiratory drive, preserved respiratory muscle strength, and near-normal lung volumes. ${ }^{7}$ Hypothetically, early intubation and control of the ventilatory pattern might mitigate the severity of respiratory failure. ${ }^{15,16}$ Third, early reports from China described sudden, acute respiratory destabilization in 46-65\% of patients with COVID-19 in the ICU, ${ }^{17,18}$ raising apprehension of delayed detection in overwhelmed hospitals. ${ }^{15,19,20}$ Thus preemptive intubation appeared reasonable from a safety perspective.

The counterargument, colloquially referred to as "avoid intubation at all costs," ${ }^{21}$ was largely driven by the following rationale. Early on invasive ventilation was associated with extraordinarily high mortality $(70-100 \%) .22-25$ Also, severely hypoxemic patients initially appeared stable, with relatively intact pulmonary mechanics and respiratory muscle reserve, often without apparent respiratory distress ("silent hypoxemia"). ${ }^{5,26}$ Again, in the context of overwhelmed clinicians and a looming (sometimes actual) shortage of ventilators, forestalling intubation with noninvasive respiratory therapies appeared rational and pragmatic. ${ }^{8}$ In terms of infection control, the evidence, as it existed, strongly suggested that the primary risk for clinician infection was not NIV or high-flow nasal oxygen, but rather intubation and associated periods of bag-mask ventilation. ${ }^{27}$

\section{Is This Really ARDS?}

"Taxonomy is described sometimes as a science, sometimes as an art, but really it's a battleground." -Bill Bryson ${ }^{28}$

The second controversy was that COVID-19-induced respiratory failure differed substantially from ARDS. This raised questions whether invasive ventilation practices should deviate from current evidence-based lung-protective ventilation (LPV) guidelines and protocols. The controversy ranged from circumspect, well-reasoned, tentative opinions (based upon decades of ARDS research) ${ }^{7,8}$ to skewed interpretations regarding the Berlin definition criteria for syndrome onset, ${ }^{29}$ to ill-informed conjecture such as COVID-19 resembling high-altitude (ie, "hydrostatic") pulmonary edema rather than altered permeability pulmonary edema (the quintessential feature of ARDS). ${ }^{30}$

Whether COVID-19 respiratory failure differs from ARDS should, as a first step, refer back to the definitions of taxonomy and syndrome. Taxonomy refers to how phenomena are organized or classified according to common attributes. By its nature, taxonomy is rule-based, which to some degree is unavoidably arbitrary and thus prone to controversy. Syndrome, derived from the Greek word for "concurrence," refers to a set of co-related signs and symptoms associated with a particular disease or disorder. ARDS represents an effect emanating from a multitude of potential initiating sources causing acute pulmonary tissue injury and an inflammatory response. These result in varying degrees of severity of both epithelial and endothelial injury, altered permeability pulmonary edema, altered lung mechanics, and hypoxemia.

As such, the definition of ARDS requires that it be based on common attributes for making a classification when numerous pathogenic agents can initiate lung injury, these attributes being: (1) a specific threshold of oxygenation dysfunction using the ratio of arterial partial pressure of oxygen to inspired oxygen fraction $\left(\mathrm{P}_{\mathrm{aO}_{2}} / \mathrm{F}_{\mathrm{IO}_{2}}\right) \leq 300 \mathrm{~mm} \mathrm{Hg}$ (ie, an approximation of the traditional hypoxemia threshold of $\sim 60 \mathrm{~mm} \mathrm{Hg}$ on room air); (2) radiographic presentation of bilateral lung opacities suggestive of disseminated alveolar injury; and (3) an inciting mechanism (etiology) known or suspected to cause acute lung injury.

Although the definition of ARDS has evolved since 1967 (albeit with controversy), these defining characteristics have not fundamentally changed. Most relevant to COVID19 is that viral pneumonia accounted for $33 \%$ of subjects first described as having ARDS in the seminal 1967 paper by Ashbaugh et al. ${ }^{31}$ In addition, evidence suggests that ARDS was the primary cause of early mortality during the 1918 H1N1 pandemic. ${ }^{32}$ Since 1967, multiple viruses have been associated with the syndrome, including influenza, adenovirus, varicella, hantavirus, and coronavirus. ${ }^{2}$ In early reports from China, $65-85 \%$ of patients with COVID-19 who were admitted to the ICU met ARDS criteria. ${ }^{33,34}$

Part of the controversy rests with the fact that radiographic evidence of ARDS has always been the most vulnerable criterion given the high degree of inter-observer variability (even among experts). ${ }^{35}$ In addition, a telling observation was that radiologically "COVID-19 lung involvement is unique having a pneumonia pattern rather than a typical ARDS pattern at least in the initial phase during the first days after intubation" [italics added] ${ }^{36}$ Implicit in this statement is that severe hypoxemia was associated with initial lobar pneumonia. In addition, the speed of acute lung injury progression in viral ARDS is dependent upon the speed of viral replication, which differs between viruses (eg, H1N1 vs SARS CoV-1), ${ }^{32}$ and perhaps between SARS $\mathrm{CoV}-2$ variants as well. Another underlying contributing factor has been the tendency toward under-recognition of ARDS in clinical practice. ${ }^{37}$

Finally, a misreading of Berlin definition criteria likely played a role. A review paper cited 3 early studies from China in which the median time from symptom onset to ARDS was 8-12 d. ${ }^{29}$ Although the time frame exceeds the criterion established by the Berlin Definition Taskforce, ${ }^{38}$ the authors did not use the full description, which included "or new or worsening respiratory symptoms" (ie, underlying disease progression as alluded to above). Interestingly, the "7 d from onset" criterion was based on a single-center study of 182 subjects with risk factors who subsequently developed ARDS, but excluded pneumonia as a risk 
factor. ${ }^{39}$ Between $35 \%$ and $56 \%$ of subjects enrolled into large prospective ARDS treatment trials had pneumonia as the primary etiology, thus limiting the external validity upon which the 7-d criterion was initially based. ${ }^{40-44}$

\section{The Theory of ARDS Phenotypes}

Phenotypes are the observable characteristics of an organism (eg, physical, morphologic, biochemical), whereas genotype refers to an organism's entire catalogue of genes available for potential expression. Phenotypes represent an interaction between the organism's genotype and the environment it encounters. Specific to ARDS, this would include infectious or other injurious agents and the therapies used to treat it (eg, invasive ventilation, hyperoxia, pharmacologic agents). In COVID-19-associated ARDS, use of the term phenotype created more controversy than clarity. ${ }^{45-50}$ Regardless of etiology, individual responses to acute lung injury exist along a spectrum, ranging from mild to severe, that involves the interplay of several factors.

In ARDS, phenotypic expression would encompass either the propensity or disinclination for developing a hyperimmune response to acute lung injury (ie, cytokine storm syndrome). ${ }^{51,52}$ An individual's genetic susceptibility would also apply to the propensity for developing hyperoxic acute lung injury ${ }^{53}$ and ventilator-induced lung injury. ${ }^{54}$ Prior to COVID-19, interest in ARDS phenotypes focused on apparent hypo- or hyperinflammatory (ie, reactive) responses to acute lung injury. Hyperinflammatory phenotypes are thought to occur in $\sim 33 \%$ of ARDS cases, are associated with severe ARDS, and perhaps are more responsive to PEEP, certain pharmacologic therapies, and conservative fluid management. ${ }^{55-57}$

However, it is difficult to disentangle an individual's response to COVID-19-induced lung injury from numerous inter-related factors such as the magnitude of infectious insult (including the potential impact of SARS CoV-2 variants), the usual stages of pneumonia progression, ${ }^{50}$ the presence of comorbidities, abnormal body habitus (ie, the extent to which it exaggerates hydrostatic forces that worsen chest mechanics, gas exchange and radiographic findings), and the intensity and duration of exposures to hyperoxia and injurious ventilation patterns. There also exists the inherent problems of conducting physiologic research in the critical care setting (eg, selection bias, small sample sizes), problems that are magnified under pandemic conditions.

The most succinct criticism of phenotyping COVID-19 was that it was premature. ${ }^{46}$ First and foremost, it preceded systematic, unbiased data collection that ultimately leads to "a phenotypic signature specific to high gene expression." ${ }^{46}$ Second, the attempt was based on single- center data and "anchored on only one or two clinically apparent variables." 46

\section{COVID-19 Phenotypes}

The COVID-19 phenotypes hypothesis was raised early on in editorials on the basis of observations initially made in an undisclosed number of subjects, and subsequently reported as being made in 150 subjects. ${ }^{7,8}$ The basis was severe hypoxemia dissociated from corresponding reductions in respiratory system compliance $\left(\mathrm{C}_{\mathrm{RS}}\right)$ usually observed in ARDS. Consequently it was proposed that COVID-19-associated respiratory failure be classified as non-ARDS (Type 1) and ARDS (Type 2). ${ }^{8}$ Of note, the term "non-ARDS" was quickly modified to "atypical ARDS." 58

In Type 1 COVID-19, computed tomography (CT) imaging showed essentially normal gas volume and minimal $(\sim 8 \%)$ non-aerated lung tissue associated with normal $C_{R S}$ $\left(80 \mathrm{~mL} / \mathrm{cm} \mathrm{H}_{2} \mathrm{O}\right)$ and disproportionately elevated venous admixture $(56 \%)$. This was attributed to severe ventilationperfusion mismatching caused by loss of compensatory hypoxemic vasoconstriction (from viral injury of the pulmonary vascular endothelium), rather than intrapulmonary shunt from large amounts of nonaerated tisssue. ${ }^{7}$ In contrast, Type 2 COVID-19 exhibited a classic ARDS profile with markedly reduced lung volume ( $~ 60 \%$ of normal) with $39 \%$ nonaerated lung tissue and both venous admixture and $\mathrm{C}_{\mathrm{RS}}$ typically found in ARDS ( $49 \%$ and $43 \mathrm{~mL} / \mathrm{cm}$ $\mathrm{H}_{2} \mathrm{O}$, respectively).

The proposed phenotypes were later renamed from Type 1 to Type L (ie, low lung elastance or high "preserved" lung compliance) and from Type 2 to Type $\mathrm{H}$ (ie, high lung elastance or low lung compliance) on the basis of data culled from 150 subjects. ${ }^{7}$ In addition to describing these archetypal presentations of COVID-19 respiratory failure, the authors (as well as others) suggested a modified approach to ventilator management (Table 1). ${ }^{7,15,20}$

\section{COVID-19 Phenotypes and LPV}

The ensuing controversy over modifying LPV for COVID-19 focused primarily on liberalizing $\mathrm{V}_{\mathrm{T}}$ in steps from $6 \mathrm{~mL} / \mathrm{kg}$ to 7,8 , and perhaps $9 \mathrm{~mL} / \mathrm{kg}$ when hypercapnia or severe dyspnea were present, and only in those patients presenting as Type L. ${ }^{7,8}$ In other words, this approach would be applied to patients in whom lung volume is well preserved so that the risk of developing ventilator-induced lung injury (VILI) would be relatively minor and a reasonable trade-off to balance other risk factors.

Liberalized $\mathrm{V}_{\mathrm{T}}$ within accepted LPV parameters has been a consistent feature of European studies for decades. ${ }^{59-67} \mathrm{In}$ addition, the 2016 LUNG SAFE international survey also used $8 \mathrm{~mL} / \mathrm{kg}$ as the upper threshold for LPV. ${ }^{63}$ Moreover, 
Table 1. Proposed COVID-19 Phenotypes of Respiratory Failure and Early Management Recommendations*

\begin{tabular}{|c|c|c|}
\hline & Type L & Type H \\
\hline Original designation & Type 1 & Type 2 \\
\hline Time course & Early & Late \\
\hline Defining characteristic & Preserved lung compliance (ie, low lung elastance) & $\begin{array}{l}\text { Decreased lung compliance (ie, high lung } \\
\text { elastance) }\end{array}$ \\
\hline $\mathrm{C}_{\mathrm{RS}}$ demarcation & $\geq 50 \mathrm{~mL} / \mathrm{cm} \mathrm{H}_{2} \mathrm{O}$ & $<40 \mathrm{~mL} / \mathrm{cm} \mathrm{H}_{2} \mathrm{O}$ \\
\hline Chest CT findings & $\begin{array}{l}\text { Preserved lung volume } \\
\text { Decreased \% nonaerated lung tissue }\end{array}$ & $\begin{array}{l}\text { Decreased lung volume } \\
\text { Increased \% nonaerated lung tissue }\end{array}$ \\
\hline Lung weight & Normal & Increased \\
\hline Most salient gas exchange characteristic & $\begin{array}{l}\text { Severe hypoxemia disproportionate to percentage } \\
\text { nonaerated lung tissue }\end{array}$ & $\begin{array}{l}\text { Severe hypoxemia proportionate to percentage } \\
\text { nonaerated lung tissue }\end{array}$ \\
\hline $\begin{array}{l}\text { Primary source of severe hypoxemia } \\
\text { Lung-protective ventilation settings }\end{array}$ & Decreased $\dot{\mathrm{V}} / \dot{\mathrm{Q}}$ & Increased intrapulmonary shunt fraction \\
\hline $\mathrm{V}_{\mathrm{T}}, \mathrm{mL} / \mathrm{kg}$ & $6-9^{\dagger}$ & $\leq 6$ \\
\hline Breathing frequency, breaths/min & $15-20$ & Not specified \\
\hline PEEP, $\mathrm{cm} \mathrm{H}_{2} \mathrm{O}$ & $8-10$ & $\geq 14$ \\
\hline Prone positioning & $\begin{array}{l}\text { "Rescue therapy": increased } \dot{\mathrm{V}} / \dot{\mathrm{Q}} \text {; prolonged } \\
\text { prone duration not advised, marginal benefit at } \\
\text { best (ie, minimal lung recruitment potential) }\end{array}$ & $\begin{array}{l}\text { Prolonged course }(16-20 \mathrm{~h} / \mathrm{d}) \text { to facilitate lung } \\
\text { recruitment; substantial benefit likely as in non- } \\
\text { COVID-19 ARDS }\end{array}$ \\
\hline Inhaled vasodilators & $\begin{array}{l}\text { Questionable benefit due to loss of apparent } \\
\text { "vasoplegia" (ie, loss of vasomotor tone) }\end{array}$ & $\begin{array}{l}\text { Potential benefit as pulmonary hypertension is } \\
\text { associated with severe non-COVID-19 ARDS, } \\
\text { speculation that partial resolution of vasoplegia } \\
\text { might occur over disease course }\end{array}$ \\
\hline $\begin{array}{l}\text { * Based on References } 7 \text { and } 8 . \\
{ }^{+} \text {Increases }>6 \text { only for hypercapnia or attempting to } \mathrm{r} \\
\mathrm{C}_{\mathrm{RS}}=\text { respiratory system compliance } \\
\mathrm{CT}=\text { computed tomography } \\
\dot{\mathrm{V}} / \mathrm{Q}=\text { ventilation-to-perfusion ratio } \\
\mathrm{V}_{\mathrm{T}}=\text { tidal volume }\end{array}$ & e dyspnea (rather than increasing breathing frequency). & \\
\hline
\end{tabular}

the Surviving Sepsis Campaign Guidelines for COVID-19 recommended a $\mathrm{V}_{\mathrm{T}}$ of $4-8 \mathrm{~mL} / \mathrm{kg}$. ${ }^{68}$ The insinuation that these circumscribed guidelines deviated from accepted LPV norms was highly misleading. ${ }^{46,69}$ Furthermore, these recommendations are in stark contrast to others who suggested COVID-19 can be managed safely with a $\mathrm{V}_{\mathrm{T}} \leq 11 \mathrm{~mL} / \mathrm{kg}$ (assuming that plateau pressure was $\leq 32 \mathrm{~cm} \mathrm{H}_{2} \mathrm{O}$ ). ${ }^{6,70}$

Reasonable liberalizing of $\mathrm{V}_{\mathrm{T}}$ from 6 to $7-8 \mathrm{~mL} / \mathrm{kg}$ was based upon observations that it often attenuates dyspnea ${ }^{8}$ and is supported indirectly by studies on $\mathrm{V}_{\mathrm{T}}$ demand during LPV (see the supplementary materials at http://www. rcjournal.com). ${ }^{71} \mathrm{~A}$ peculiar aspect of arguments against liberalizing $\mathrm{V}_{\mathrm{T}}{ }^{72,73}$ is that they conveniently ignored discussing the reliance upon sedation to control dyspnea and asynchrony, which also carries substantial risk of harm. ${ }^{74-76}$ A decade ago, evidence suggested that patient-ventilator asynchrony was associated with worse outcomes, ${ }^{77}$ and more recent evidence suggests that persistent, severe patient-ventilator asynchrony may be particularly harmful. ${ }^{78}$ In this context, the issue of whether patient selfinflicted lung injury is a factor in COVID-19 progression (and its potential exacerbation by dyspnea frequently associated with $\mathrm{V}_{\mathrm{T}}$-mismatching during $\mathrm{LPV}$ ) raises legitimate cause for concern.
The second controversy focused on how PEEP should be applied. The Surviving Sepsis Guidelines for COVID-19 suggesting a higher PEEP strategy over a lower PEEP strategy (ie, PEEP $>10 \mathrm{~cm} \mathrm{H}$ O) drew particular criticism. ${ }^{68}$ In response, an editorial pointing out the vague nature of the criticism replied that "higher PEEP does not necessarily imply very high levels of PEEP." 79 That statement was made in the context of remarking upon a small PEEP study for which it was written. ${ }^{80}$ In that study, borderline super-PEEP (18 $\mathrm{cm} \mathrm{H}_{2} \mathrm{O}$ ) applied in Type $\mathrm{L}$ subjects with relatively preserved $\mathrm{C}_{\mathrm{RS}}\left(58 \mathrm{~mL} / \mathrm{cm} \mathrm{H}_{2} \mathrm{O}\right)$ markedly improved oxygenation and end-expiratory lung volume but at the predictable expense of overdistention and hemodynamic impairment. ${ }^{80}$ Similarly, investigators in Greece observed relatively preserved $\mathrm{C}_{\mathrm{RS}}\left(50-65 \mathrm{~mL} / \mathrm{cm} \mathrm{H}_{2} \mathrm{O}\right)$ with median "best PEEP" levels of only $8 \mathrm{~cm} \mathrm{H}_{2} \mathrm{O}$. This led them and others to criticize use of pre-defined PEEP such as the ARDSNet $\mathrm{PEEP} / \mathrm{F}_{\mathrm{IO}_{2}}$ tables and recommended their abandonment in most COVID cases. ${ }^{6,36,81}$

\section{Phenotypes Versus Disease Evolution in COVID-19}

Early reports regarding COVID-19 phenotypes were limited by the lack of specific data despite claims that this idea 
was based on "detailed observation of several patients and discussions with colleagues" and "more than $50 \%$ of the 150 patients measured by the authors and confirmed by several colleagues in Northern Italy." "This initial description was quickly followed by specific data from 16 subjects showing that mean $\mathrm{C}_{\mathrm{RS}}$ of $50 \pm 14$ coincided with mean pulmonary shunt of $0.50 \pm 0.11 .{ }^{58}$ Yet the first detailed mechanical ventilation study from Italy on COVID-19 phenotypes did not appear until October 2020 and included data from only 32 subjects. ${ }^{67}$

A striking comment was that COVID-19-associated ARDS "as the same disease" presents itself with impressive non-uniformity and that such a wide discrepancy (between magnitude of hypoxemia and corresponding severity in reduced $C_{R S}$ ) is almost never seen in severe ARDS. ${ }^{7,58}$ These observations were accompanied by pro forma statements listing potential confounding factors such as the combined effects of infection severity and host response, variability in individual responses to hypoxemia, and (particularly crucial to their hypothesis), that the duration between disease onset and observation would lead to a time-related disease spectrum with 2 primary "phenotypes."

In other words, COVID-19 ARDS likely evolves over time and transitions from a mild to a severe phenotype that, based on the timing of presentation (scientific observation), may present "insurmountable methodological challenges" to study. ${ }^{7,82}$ But liberalizing the definition of ARDS phenotypes from hypo- versus hyperimmune response to one suggesting that apparent variations in COVID-19 expression somehow fundamentally differ from the non-uniformity observed in ARDS (irrespective of etiology) is highly suspect in its reasoning (see the supplementary materials at http://www.rcjournal.com).

\section{Conflicting Evidence Regarding COVID-19 Phenotypes}

Last September, data from 38 subjects with COVID-19associated ARDS contradicted the idea of phenotypes. ${ }^{83} \mathrm{In}$ these subjects, chest CT imaging (using nonquantitative analysis) performed directly after intubation revealed that only $\sim 35 \%$ met either Type L or Type H criteria. The majority represented discordant results regarding the lack of association between $\mathrm{C}_{\mathrm{RS}}$ and the amount of poorly or nonaerated tissue, suggesting wide overlap in presentations.

The following month, proponents of the COVID-19 phenotype concept published an in-depth study on the gas exchange, pulmonary mechanics, and CT findings alluded to in their early editorials. ${ }^{67}$ In this case-control comparison, subjects with confirmed COVID-19-associated ARDS were matched 1:1 with 2 separate non-COVID-19 ARDS cohorts by $\mathrm{P}_{\mathrm{aO}}$ and by $\mathrm{C}_{\mathrm{RS}}$. CT quantitative analysis of lung tissue was performed at a standardized PEEP of $5 \mathrm{~cm} \mathrm{H}_{2} \mathrm{O}$ (ie, removing the confounding effects of therapeutic lung recruitment from assessing baseline pathophysiology). Subjects with ARDS due to COVID-19 shared similar amounts of poorly aerated lung tissue with subjects in the $\mathrm{P}_{\mathrm{aO}} / \mathrm{F}_{\mathrm{IO}_{2}}$-matched ARDS cohort, but in almost every other aspect they more closely resembled subjects in the $\mathrm{C}_{\mathrm{RS}}$-matched ARDS cohort (see the supplementary materials at http://www.rcjournal.com).

The discrepancies between these studies reflects the inevitable limitations imposed by small sample sizes. Possible differences between the studies likely included timing of measurements relative to disease onset. This is particularly relevant given radiographic reports that rapid progression of lesions was sometimes observed. ${ }^{84,85}$ The lack of standardization of ventilator settings in 1 trial $^{83}$ and differences between non-quantitative and quantitative analysis of CT scans across the studies may have influenced their interpretation.

\section{Pathologic and Radiologic Features of COVID-19}

Finally, the existence of proposed COVID-19 phenotypes is inextricably tied to the declaration that they represent a time-related disease spectrum. ${ }^{7}$ Such a statement requires reviewing both the pathologic and radiologic evidence in COVID-19-associated respiratory failure. A brief letter describing 6 postmortem exams observed that COVID-19-associated lung injury progressed over time. ${ }^{86}$ Findings in subjects who died $5 \mathrm{~d}$ after symptom onset revealed lymphocytic pneumonia with both interstitial and alveolar infiltration consistent with a Type L presentation. The 5 other subjects who died at $\sim 20 \mathrm{~d}$ all presented with acute fibrinous organizing pneumonia and extensive intraalveolar and bronchiolar involvement, as well as endothelial injury consistent with Type $\mathrm{H}$ presentation.

A subsequent study of 41 subjects compared histopathologic findings between subjects who died at varying time points. ${ }^{87}$ Findings among subjects who died within the first $8 \mathrm{~d}$ differed from those who died afterwards. The first cohort exhibited a predominantly exudative pattern with interstitial and intra-alveolar edema and varying degrees of alveolar hemorrhage, fibroblastic proliferation, and hyaline membrane formation. Subjects who died 17-40 d after symptom onset largely presented with fibroblastic proliferation with densely fibrotic areas. Across study time frames, pulmonary microthrombosis was frequently observed. The histopathologic pattern and time-dependent evolution of diffuse alveolar damage found in subjects with COVID-19associated ARDS was "stereotypical" of that observed in non-COVID-19-associated ARDS. ${ }^{87}$ Another study observed an early stage characterized by neutrophilic, exudative capillaritis with microthrombosis in contrast to a later stage with a classic ARDS presentation of diffuse alveolar damage and ongoing intravascular thrombosis in small to medium sized vessels. ${ }^{88}$ 
Radiologic findings regarding COVID-19 progression were consistent with those found at autopsy. CT imaging in 63 subjects was compared between initial examination and reexamination between days $3-14 .{ }^{85}$ Initial examination noted that $30 \%$ of subjects had only single lobe involvement, whereas $\sim 55 \%$ had involvement in 4-5 lobes with patchy/punctate ground glass opacities as the primary characteristic. Reexamination revealed variable (sometimes rapid) disease progression with diffuse lesions of increasingly dense ground glass opacities and tissue consolidation (ie, "white lung"). The investigators' general impression was that CT imaging of COVID-19 was similar to common viral pneumonia. ${ }^{85}$

\section{Renin-Angiotensin System and Hypoxemia in COVID-19}

Dysregulation of compensatory hypoxemic pulmonary vasoconstriction in Type $\mathrm{L}$ phenotype aligns with the fact that SARS CoV-2 pulmonary infection primarily targets angiotensin-converting enzyme 2 receptors (ACE II) of the pulmonary endothelium. ${ }^{89}$ In brief, ACE II receptors are part of the renin-angiotensin system in which the hormone angiotensin causes vasoconstriction. ACE is abundantly produced by the capillary endothelium and plays a major role in maintaining ventilation-perfusion balance in response to hypoxemia. ${ }^{90}$ ACE II receptors also are found in both airway and alveolar epithelial cells, with emerging evidence that angiotensin plays a prominent (albeit complicated) role in the inflammatory response to both ARDS and ventilator-induced lung injury. ${ }^{90}$

An alternative explanation is that infected alveolar epithelial cells downregulate ACE II activity causing unopposed ACE I activity in neighboring endothelial cells. Although this would trigger a disproportionate release of endothelin-1 (a potent pulmonary vasoconstrictor) causing recruitment of pulmonary capillary beds, ${ }^{50}$ the end result would be similar: severe hypoxemia from ventilation-perfusion mismatching.

\section{Observation and Interpretation During a Global Medical Crisis}

Thus, both pathologic and radiographic findings suggest that what was initially interpreted as different COVID-19 phenotypes appears simply to be disease progression. This is likely attributable to a confluence of factors, including the timing of observation relative to a variable disease progression. More importantly, scientific inquiry normally affords the luxury of open-ended contemplation prior to publication. The COVID-19 pandemic afforded no such luxury. Enormous pressure likely was felt by preeminent ARDS researchers to quickly make some sense of their preliminary observations and convey them to a global audience struggling to understand, let alone manage, a novel viral pandemic. These observations appear concordant with those penned by Dr Gattinoni and colleagues toward the end of $2020 .{ }^{91}$

\section{The Theory of Patient Self-Inflicted Lung Injury}

The earliest description of COVID-19 ARDS pathogenesis posited that a minority of patients (20-30\%) who either initially presented as (or later transitioned to) Type $\mathrm{H}$ phenotypes may have had their disease course exacerbated by patient self-inflicted lung injury from spontaneous breathing at a supranormal $\mathrm{V}_{\mathrm{T}}$ and high transalveolar pressures. ${ }^{7}$ Prolonged inspiratory efforts resulting in both excessive pleural pressure swings $\geq 15 \mathrm{~cm} \mathrm{H}_{2} \mathrm{O}$ and $\mathrm{V}_{\mathrm{T}}$ $(\geq 15 \mathrm{~mL} / \mathrm{kg}$ ) were proposed to cause or perpetuate acute lung injury. ${ }^{7}$ Because severe SARS CoV-2 infection involves the vascular endothelium, it was further suggested that the carotid bodies may become hypersensitive to hypoxemia, causing abnormally heightened respiratory drive (ie, disproportionate to the severity of hypoxemia) and thus contributing to patient self-inflicted lung injury. ${ }^{92}$

Strenuous diaphragmatic contractions would normally cause high negative pleural pressures to be transmitted homogeneously across healthy lungs (ie, fluid behavior), thus minimizing abnormal strain-stress development. But heterogeneously injured lungs dissipate pressure unevenly, so that stress becomes amplified at the interfaces between collapsed/consolidated tissue and surrounding normally aerated tissue (ie, solid behavior). This results in greater inflammation and edema formation, particularly in dependent lung regions. ${ }^{93}$

Preclinical evidence has demonstrated that high $\mathrm{V}_{\mathrm{T}}$ ventilation generated by negative transpulmonary pressure induces acute lung injury in normal lungs. ${ }^{94,95}$ In acutely injured lungs undergoing assisted ventilation, doxapram-induced inspiratory efforts resulting in only a moderate $\mathrm{V}_{\mathrm{T}}(\sim 8 \mathrm{~mL} / \mathrm{kg})$ but transpulmonary pressures $\geq 30$ $\mathrm{cm} \mathrm{H}_{2} \mathrm{O}$ produced the greatest degree of lung collapse, hyperinflation, and histologic injury within a matter of only 4 h. ${ }^{96}$

Clinical evidence supporting patient self-inflicted lung injury remains speculative. First, in both COVID-19-associated and non-COVID-19-associated ARDS alike, patient self-inflicted lung injury would likely follow the 2-hit theory of lung injury, whereby the initial insult would prime the immune system, with subsequent high stressstrain ventilation further intensifying inflammation. ${ }^{97,98}$ Second, a relatively safe plateau pressure $\left(\mathrm{P}_{\text {plat }}\right)$ of $\leq 30 \mathrm{~cm}$ $\mathrm{H}_{2} \mathrm{O}$, traditionally advocated for LPV, assumes normal chest wall compliance, so that the projected peak transalveolar stress would not exceed $20 \mathrm{~cm} \mathrm{H}_{2} \mathrm{O} .{ }^{99}$ In addition, tidal stress change (ie, $\mathrm{P}_{\text {plat }}-\mathrm{PEEP}>15 \mathrm{~cm} \mathrm{H}_{2} \mathrm{O}$ ) has been 
shown to increase mortality risk. ${ }^{100}$ But when examining Figure 2 from the study by Amato et al, ${ }^{100}$ it is apparent that the inflection point for mortality risk becomes pronounced only at $\sim 20 \mathrm{~cm} \mathrm{H}_{2} \mathrm{O}$, which was associated with a median $\mathrm{V}_{\mathrm{T}}$ of $8 \mathrm{~mL} / \mathrm{kg}$.

Finally, the plausibility of patient self-inflicted lung injury has been documented in acute lung injury. Spontaneous breathing efforts during assisted ventilation in pneumonia or non-pulmonary sepsis produced median (interquartile range [IQR]) transpulmonary pressures of 18 (IQR 14-23) $\mathrm{cm} \mathrm{H}_{2} \mathrm{O} .{ }^{101}$ Likewise, median (IQR) negative esophageal pressure swings of 17 (IQR 12-22) $\mathrm{cm} \mathrm{H}_{2} \mathrm{O}$ have been reported during unassisted breathing in ARDS, with individual measurements as high as 31 $\mathrm{cm} \mathrm{H}_{2} \mathrm{O} .{ }^{102}$ Subjects recovering from COVID-19-associated ARDS generated large negative intrathoracic pressures during weaning. ${ }^{103}$ Of particular interest, subjects who developed relapse respiratory failure $24 \mathrm{~h}$ after a weaning trial generated greater negative pressure swings than those who did not (18 [IQR 15-26] vs 15 [IQR 7$18] \mathrm{cm} \mathrm{H}_{2} \mathrm{O}$ ), and several subjects generated pressure swings $\geq 30 \mathrm{~cm} \mathrm{H}_{2} \mathrm{O} .{ }^{103}$ In subjects with acute hypoxemic respiratory failure (78\% with ARDS), generating a spontaneous $\mathrm{V}_{\mathrm{T}}>9.5 \mathrm{~mL} / \mathrm{kg}$ was independently associated with NIV failure. ${ }^{104}$ Moreover, it was observed that maintaining a $\mathrm{V}_{\mathrm{T}}$ of $6-8 \mathrm{~mL} / \mathrm{kg}$ was possible in only $23 \%$ of subjects despite pressure support levels used in spontaneous breathing trials (ie, $7 \mathrm{~cm} \mathrm{H}_{2} \mathrm{O}$ ). This underscores the general difficulty of maintaining LPV goals in critically ill patients with heightened respiratory drive.

\section{Invasive Ventilation Usage and Associated Mortality}

Concern during the first months of the pandemic focused on extraordinarily high mortality associated with invasive ventilation. This was based largely on 4 studies with $<500$ cases. $^{22-25}$ That Chen and colleagues ${ }^{25}$ reported all 17 invasively ventilated subjects died may have garnered disproportionate attention.

By the end of 2020, a large number of studies that included data on invasive ventilation had been published (see the supplementary materials at http://www.rcjournal. com). ${ }^{22-25,34,105-127}$ Regarding the need for invasive ventilation, 32 observational studies with $>15,000$ subjects reported median (IQR) usage of 23\% (IQR 13-54\%) with a corresponding mortality of $49 \%$ (IQR $31-70 \%$ ). Some of the highest mortality rates $(\geq 80 \%)$ were reported early on from countries and regions ravaged by the pandemic. ${ }^{24,25,34,105,126}$ These represented the least prepared areas and prior to discovering effective pharmacologic therapies. ${ }^{128}$

Because it was imperative to disseminate even preliminary information during the crisis, more than half of these studies ceased data collection prior to hospital discharge and before establishing definitive outcome data. An international meta-analysis attempted to compensate for this by estimating both the lowest and highest possible mortality rates (ie, assuming all outstanding cases either survived or succumbed to COVID-19). ${ }^{129}$ These estimates ranged from a lowest mortality rate of $43 \%$ (95\% CI 36-51\%) to a highest mortality rate of $64 \%$ (95\% CI 56-72\%). When restricted to completed outcome data, the mortality rate was 49.5\%. Another international study focused on hospital mortality differences on the basis of "organ support."130 Among hospitalized subjects who did not require invasive ventilation, renal replacement therapy, or vasopressor therapy, the mortality rate was only $8 \%$. In contrast, the mortality rate was $40.8 \%$ in those who required only mechanical ventilation and increased to $71.6 \%$ in those who required dialysis and vasopressor support (ie, multiple organ dysfunction syndrome).

For perspective, observational studies of ARDS in the LPV era have reported 95\% CI for mortality of 31-39\% (mild), 37-43\% (moderate), and $42-50 \%$ (severe). ${ }^{63}$ Similar to COVID-19, when ARDS was associated with renal failure, mortality risk increased to $80 \%$ in some studies. ${ }^{131}$ COVID-19 mortality associated with invasive ventilation is similar to that observed during the SARS CoV-1 pandemic (45-48\%), ${ }^{132,133}$ and lower than that observed with the Middle East respiratory syndrome coronavirus (MERS-CoV) epidemic $(60-74 \%){ }^{134-136}$

\section{Invasive Ventilation Duration}

Prolonged invasive ventilation has also been observed with COVID-19. ${ }^{110}$ In the aforementioned studies, 16 reported duration as it pertained to survivors, time to first successful extubation trial, or the presence of multipleorgan system dysfunction. With one exception, central tendency exceeded a week. ${ }^{117}$ Another study reported that duration was not appreciably different between survivors and nonsurvivors; moreover, in subjects intubated following NIV failure, mean duration increased from 15 to 17 days. ${ }^{125}$

Acute kidney injury and the need for renal replacement therapy had a variable impact on invasive ventilation duration depending upon outcome. ${ }^{137}$ Acute kidney injury alone increased median duration for all subjects versus survivors by 2.5 and $3.5 \mathrm{~d}$, respectively. Among those also requiring dialysis, overall median duration was unaltered (14 d) but increased substantially between survivors who required dialysis therapy compared to survivors who did not require dialysis: 28.6 (IQR 21.1-37.2) versus 15.0 (9.1-19.6) d.

This exemplifies the problem with collecting data during a pandemic. The urgent need for information virtually compels reporting incomplete outcome data distinct from established norms (eg, status at hospital discharge or at day 90). 
Table 2. Mechanical Ventilation Characteristics

\begin{tabular}{|c|c|c|c|c|c|c|}
\hline Study & Setting & Subjects, $N$ & $\mathrm{P}_{\mathrm{aO}_{2}} / \mathrm{F}_{\mathrm{IO}_{2}}, \mathrm{~mm} \mathrm{Hg}$ & $\mathrm{C}_{\mathrm{RS}}, \mathrm{mL} / \mathrm{cm} \mathrm{H} \mathrm{H}_{2} \mathrm{O}$ & PEEP, $\mathrm{cm} \mathrm{H}_{2} \mathrm{O}$ & $\mathrm{V}_{\mathrm{T}}, \mathrm{mL} / \mathrm{kg}$ or $\mathrm{mL}$ \\
\hline Chiumello et a ${ }^{67 *}$ & Single center & 32 & $107 \pm 60$ & $50 \pm 15$ & Not reported & $7.7 \pm 0.9$ \\
\hline Chiumello et al ${ }^{67 \dagger}$ & Single center & 32 & $160 \pm 62$ & $50 \pm 16$ & Not reported & $8.4 \pm 1.9$ \\
\hline $\operatorname{Bos}^{69}$ & Single center & 38 & $132 \pm 48$ & $49 \pm 24$ & $10(9-12)$ & $424 \pm 73$ \\
\hline Grasselli et a ${ }^{122}$ & Multicenter & 1,150 & $160(114-220)$ & Not reported & $14(12-16)$ & Not reported \\
\hline Liu et al $^{151}$ & Single center & 8 & $230 \pm 49$ & $34 \pm 8$ & $10 \pm 1$ & $7.5 \pm .6$ \\
\hline Botta et $\mathrm{al}^{115}$ & Multicenter & 553 & $159(129-201)$ & $32(26-40)$ & $14(11-15)$ & $6.3(5.7-7.1)$ \\
\hline COVID Critical Care Group ${ }^{116}$ & Multicenter & 4,643 & $154(103-222)$ & $33(26-42)$ & $12(10-14)$ & $6.1(5.8-6.7)$ \\
\hline Ziehr et al ${ }^{141}$ & Single center & 66 & $182(135-245)$ & $35(30-43)$ & $10(8-12)$ & Not reported \\
\hline Hernandez-Romieu et al ${ }^{120}$ & Single center & 231 & $148(111-205)$ & $34(27-47)$ & Not reported & Not reported \\
\hline Haudebourg et al ${ }^{146}$ & Single center & 30 & $111(96-128)$ & $44(35-51)$ & $10(8-12)$ & $6.0(5.9-6.7)$ \\
\hline Zangrillo et a ${ }^{142}$ & Single center & 73 & Not reported & Not reported & $12(10-14)$ & $6.7(6.0-7.5)$ \\
\hline Bhatraju et al ${ }^{143}$ & Multicenter & 24 & Not reported & $29(25-36)$ & $13(11-17)$ & Not reported \\
\hline Mitra et $\mathrm{al}^{113}$ & Single center & 117 & $180(148-216)$ & $35(31-44)$ & $12(10-14)$ & $400(350-450)$ \\
\hline Schenck et al ${ }^{110}$ & Single center & 267 & $103(82-134)$ & $28(23-38)$ & $10(8-12)$ & $7.0(6.1-8.1)$ \\
\hline Rojatta et al ${ }^{144}$ & Single center & 41 & $183 \pm 69$ & $42 \pm 19$ & $13 \pm 2$ & Not reported \\
\hline Barbeta et al ${ }^{106}$ & Single center & 50 & $174(128-232)$ & $40(33-52)$ & $13(11-14)$ & $6.8(6.3-7.3)$ \\
\hline Ferrando et al ${ }^{107}$ & Multicenter & 742 & $120(83-177)$ & $35(27-45)$ & $12(11-14)$ & $6.9(6.3-7.8)$ \\
\hline Sjoding et a $1^{145}$ & Single center & 130 & Not reported & $35(27-43)$ & $12(8-14)$ & $5.9(5.2-6.9)$ \\
\hline Lenka et $\mathrm{al}^{147}$ & Single center & 32 & Not reported & $44(31-59)$ & $16(14-20)$ & Not reported \\
\hline Brault et al ${ }^{148}$ & Single center & 24 & $101(81-126)$ & $33(26-41)$ & $12(7-15)$ & $6.1(5.4-6.8$ \\
\hline Cummings et $\mathrm{al}^{127}$ & Multicenter & 203 & $129(80-203)$ & $27(26-36)$ & $15(12-18)$ & $6.2(5.9-7.2)$ \\
\hline Diehl et al ${ }^{149}$ & Single center & 13 & $198(167-298)$ & $40(33-45)$ & $16(15-17)$ & $6.0(5.2-6.2)$ \\
\hline Vandenbunder et $\mathrm{al}^{150}$ & International multicenter & 372 & $132 \pm 53^{\ddagger}$ & $38 \pm 11$ & $12 \pm 3^{\ddagger}$ & $6.3 \pm 0.8^{\ddagger}$ \\
\hline Kassis et $\mathrm{al}^{152}$ & Single center & 40 & $150(123-182)$ & $41(34-50)$ & $14(12-15)$ & $6.2(5.8-6.7)$ \\
\hline Beloncle et a $1^{153}$ & Single center & 25 & $135(119-195)$ & Not reported & $12(10-15)$ & $6.0(5.9-6.1)$ \\
\hline Auld et al ${ }^{157}$ & Single center & 165 & $132(100-178)$ & $34(28-46)$ & Not reported & Not reported \\
\hline \multicolumn{7}{|c|}{$\begin{array}{l}\text { * Matched cases to non-COVID ARDS by } \mathrm{P}_{\mathrm{aa}_{2}} / \mathrm{F}_{\mathrm{IO}_{2}} \text {. } \\
\text { Matched cases to non-COVID ARDS by } \mathrm{C}_{\mathrm{RS}} \\
\text { } \text { Study reported mean } \mathrm{C}_{\mathrm{RS}} \text { for the entire sample and then subdivided into cohorts by a cutoff of } 35.4 \mathrm{~mL} / \mathrm{cm} \mathrm{H}_{2} \mathrm{O} \text {. As there was little distinction between cohorts in terms of, PEEP, and } \mathrm{V}_{\mathrm{T}} \text {, values of the } \\
\text { higher compliance cohort are reported. } \\
\mathrm{C}_{\mathrm{RS}}=\text { respiratory system compliance } \\
\mathrm{V}_{\mathrm{T}}=\text { tidal volume }\end{array}$} \\
\hline
\end{tabular}

As a consequence, the interpretation of invasive ventilation duration (or associated mortality) can be misleading. In one study, $35 \%$ of subjects successfully extubated had a median intubation duration of 10 (IQR 6-15) d, whereas $65 \%$ remained ventilator-dependent with median intubation duration of 18 (IQR 14-24) d when data collection stopped. ${ }^{110}$

For perspective, in randomized controlled trials of LPV in ARDS (wherein comorbidities are largely removed as a factor), the mean or median duration of invasive ventilation for lower versus higher PEEP strategies was similar to those reported for COVID-19, respectively: 13.5 and $14.2 \mathrm{~d},{ }^{40} 21$ and $25 \mathrm{~d},{ }^{44} 10 \mathrm{~d}$ each, ${ }^{43}$ and 22 and $17 \mathrm{~d} \cdot{ }^{138}$ In addition, a large observational study of weaning subjects with ARDS either by spontaneous breathing trials with daily sedation interruptions or usual care practices produced median findings within the range reported in COVID-19: 9 (IQR 4-17) and 14 (IQR 6-29) d, respectively. ${ }^{139}$

\section{PEEP and $V_{T}$ Parameters}

Twenty-three reviewed studies provided initial ventilator data (Table 2). ${ }^{83,106,107,110,113,115,116,120,127,140-153}$ In 22 of these, mean/median PEEP requirements were 10-16 $\mathrm{cm} \mathrm{H}_{2} \mathrm{O}$ (Table 2, Figure 1). A crude approach for determining the need for particularly high PEEP levels (ie, approaching the "super-PEEP" threshold of 20 $\mathrm{cm}_{2} \mathrm{O}$ ) are values demarcating $1 \mathrm{SD}$ above the mean, or the 75 th percentile. In only $4(18 \%)$ studies did these demarcation thresholds exceed $16 \mathrm{~cm} \mathrm{H}_{2} \mathrm{O}$, and only one reached $20 \mathrm{~cm} \mathrm{H}_{2} \mathrm{O} .{ }^{127,143,147,149}$ By comparison, lower range PEEP requirements (ie, demarcated by 1 SD below the mean or 25 th percentile) were twice as frequent with $36 \%$ of studies reporting values $<10 \mathrm{~cm}$ $\mathrm{H}_{2} \mathrm{O}$. For perspective, general PEEP requirements in ARDS during LPV are $10-18 \mathrm{~cm} \mathrm{H}_{2} \mathrm{O}$ for the vast 


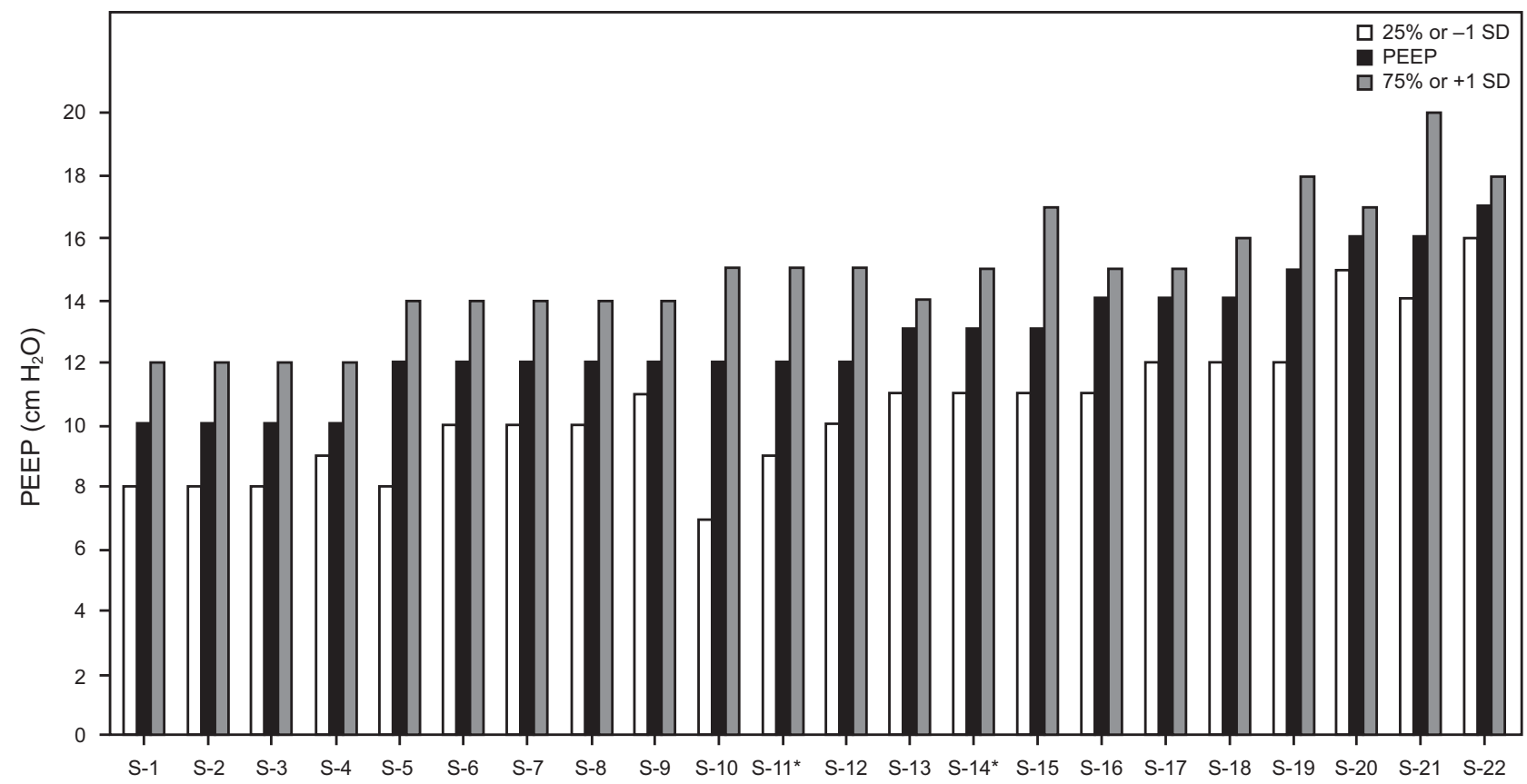

Fig. 1. Distribution of baseline PEEP requirements during invasive ventilation ordered from lowest to highest mean or median values (S denotes only the study order). Dispersion of values as either $1 \mathrm{SD}$ above/below the mean or the 25 th/75th percentile.

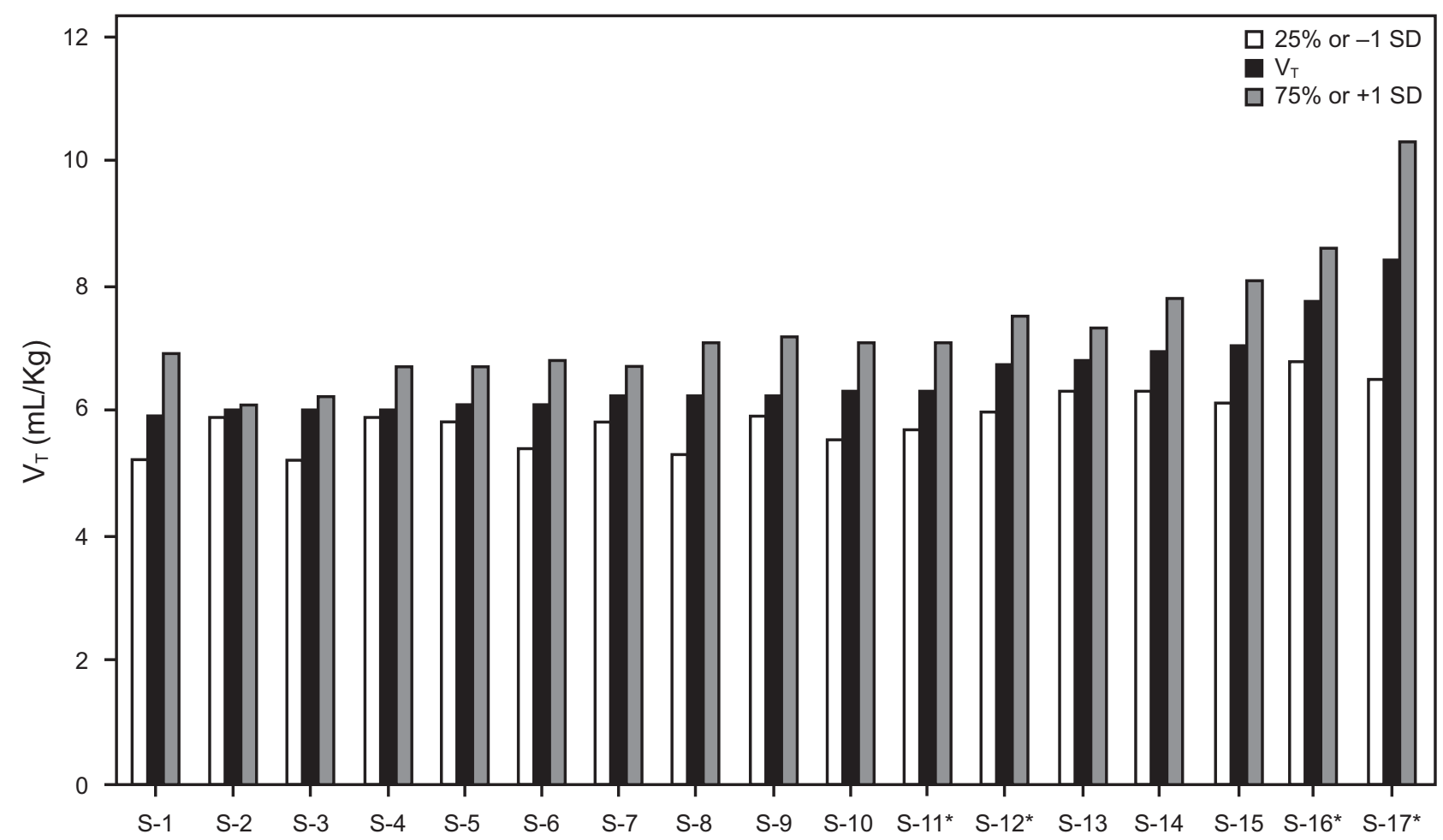

Fig. 2. Distribution of baseline tidal volume $\left(\mathrm{V}_{\mathrm{T}}\right)$ during invasive ventilation ordered from lowest to highest mean or median values $(\mathrm{S}$ denotes only the study order). Dispersion of values as either $1 \mathrm{SD}$ above/below the mean or the $25 \mathrm{th} / 75$ th percentile.

majority of patients. ${ }^{154}$ These findings suggest that PEEP requirements in COVID-19-associated ARDS are not different from the general ARDS population.
Among 18 reviewed studies reporting $\mathrm{V}_{\mathrm{T}}$ in $\mathrm{mL} / \mathrm{kg}$, $94 \%$ found mean/median values $<8 \mathrm{~mL} / \mathrm{kg}$, with $78 \%$ with values $<7 \mathrm{~mL} / \mathrm{kg}$ (Table 2, Figure 2). Using the 


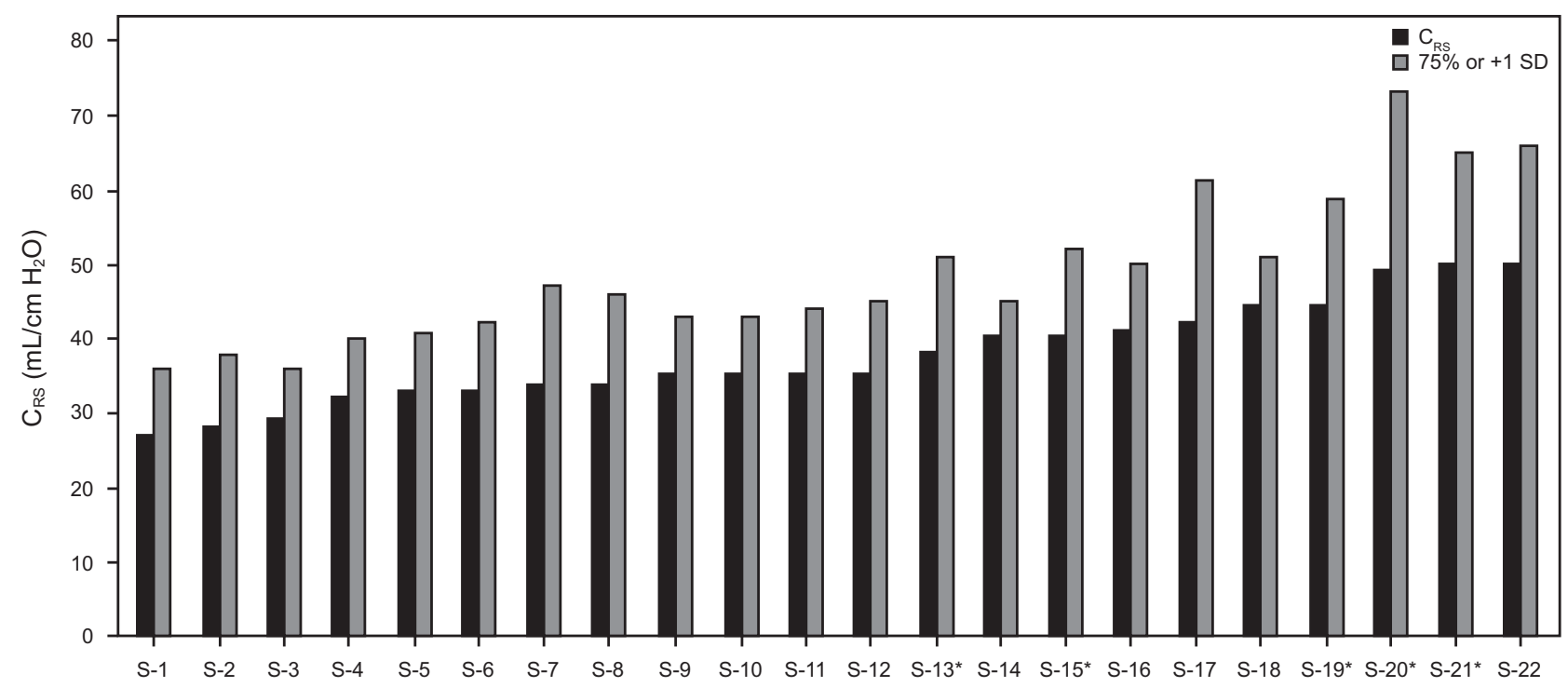

Fig. 3. Distribution of baseline respiratory system compliance $\left(C_{R S}\right)$ during invasive ventilation ordered from lowest to highest mean or median values (S denotes only the study order). Dispersion of values as either 1 SD above the mean or the 75th percentile.

demarcation points described above, violation of LPV $\mathrm{V}_{\mathrm{T}}$ parameters (ie, $>8 \mathrm{~mL} / \mathrm{kg}$ ) was reported in only $17 \%$ of studies, ${ }^{67,110}$ which suggests that $\mathrm{V}_{\mathrm{T}}$ management in COVID-19 was largely achieved within accepted LPV guidelines and liberalization was not widely practiced.

\section{Respiratory System Compliance}

Type L COVID-19 (ie, atypical ARDS) was observed in $70-80 \%$ of ventilated subjects in Italy during the first months of the pandemic. The salient characteristic were relatively preserved $\mathrm{C}_{\mathrm{RS}}$ (ie, $>50 \mathrm{~mL} / \mathrm{cm} \mathrm{H}_{2} \mathrm{O}$ ) versus Type $\mathrm{H}$ (ie, typical ARDS) demarcated by $\mathrm{C}_{\mathrm{RS}}<40 \mathrm{~cm} \mathrm{H}_{2} \mathrm{O}$ observed in only $20-30 \%$ of subjects. ${ }^{8,58}$ Given that context, studies with timeline data accompanying invasive ventilation characteristics reported that intubation occurred from 0-7 d after hospital admission, with baseline observations proceeding soon afterwards (ie, mostly subjects with early ARDS). ${ }^{107,115,120,141,146,152,153,155}$

In $68 \%$ of reviewed studies, the central tendency for $\mathrm{C}_{\mathrm{RS}}$ was $\leq 40 \mathrm{~mL} / \mathrm{cm} \mathrm{H}_{2} \mathrm{O}$, and in only $9 \%$ did it reach $50 \mathrm{~cm} \mathrm{H}_{2} \mathrm{O} .{ }^{67,69,106,107,110,113,115,120,127,141,143-152,156,157}$ This finding was similar to that for non-COVID-19-associated ARDS managed with LPV $\left(32-38 \mathrm{~mL} / \mathrm{cm} \mathrm{H}_{2} \mathrm{O}\right)^{40,44,158-160}$ but higher than that for ARDS studies preceding LPV (30-34 mL/cm H $\left.\mathrm{H}_{2} \mathrm{O}\right) .{ }^{161} \mathrm{C}_{\mathrm{RS}}$ values at $1 \mathrm{SD}$ above the mean or the 75 th percentile $\geq 50 \mathrm{~mL} / \mathrm{cm} \mathrm{H}_{2} \mathrm{O}$ were reported in $43 \%$ of studies (Figure 3) ${ }^{67,69,106,144,146,147,152}$ However, with one exception, ${ }^{67}$ the corresponding PEEP levels were $12-20 \mathrm{~cm} \mathrm{H}_{2} \mathrm{O}$; thus the relevance of higher $\mathrm{C}_{\mathrm{RS}}$ in assessing Type $\mathrm{L}$ prevalence remains uncertain. In the largest study focused on COVID-19 lung mechanics, $\mathrm{C}_{\mathrm{RS}}$ decreased over $14 \mathrm{~d}$ from $38 \pm 11$ to $31 \pm 14 \mathrm{~mL} / \mathrm{cm}$ $\mathrm{H}_{2} \mathrm{O} .{ }^{150}$ This was consistent with COVID-19 pathology examination patterns in which diffuse exudative patterns were prominent early on (ie, hospitalization day $0-8$ ) and were replaced by pronounced fibroproliferative patterns afterwards. ${ }^{87}$

Thus, contrary to initial reports from Italy, $\mathrm{C}_{\mathrm{RS}}$ was not well preserved. Even the higher dispersion of $C_{R S}$ values mostly corresponded to higher PEEP (14-20 $\mathrm{cm} \mathrm{H}_{2} \mathrm{O}$ ), which likely improved $\mathrm{C}_{\mathrm{RS}}$ relative to what was measured prior to PEEP titration (eg, conventional initial PEEP of 5 $\left.\mathrm{cm} \mathrm{H}_{2} \mathrm{O}\right) .{ }^{67}$ Nonetheless, the puzzling observations of preserved $C_{R S}$ reported in Italy were also reported anecdotally in nearby Greece. ${ }^{36,81}$ This raises an interesting possibility that perhaps a since-displaced $\mathrm{CoV}-2$ variant circulating early on in Southern Europe might have had relatively slower replication, and thus slower progression of lung injury.

\section{Lung and Chest Wall Compliance}

Prior to the advent of LPV, pathologic alterations in lung and chest wall compliance were measured in numerous studies. In studies reporting mean $\mathrm{C}_{\mathrm{RS}}$ of $30-34 \mathrm{~mL} / \mathrm{cm}$ $\mathrm{H}_{2} \mathrm{O}$, corresponding mean lung and chest wall compliances were $32-72 \mathrm{~mL} / \mathrm{cm} \mathrm{H}_{2} \mathrm{O}$ and $59-147 \mathrm{~mL} / \mathrm{cm} \mathrm{H}_{2} \mathrm{O}$, respectively, representing reductions of $40-60 \%$ and $50-80 \%$ from normal, respectively. ${ }^{161}$

Only 2 studies have reported lung and chest wall compliance in COVID-19. In a study in which median PEEP was 14 (IQR 12-15) $\mathrm{cm} \mathrm{H}_{2} \mathrm{O}$, corresponding median values for 


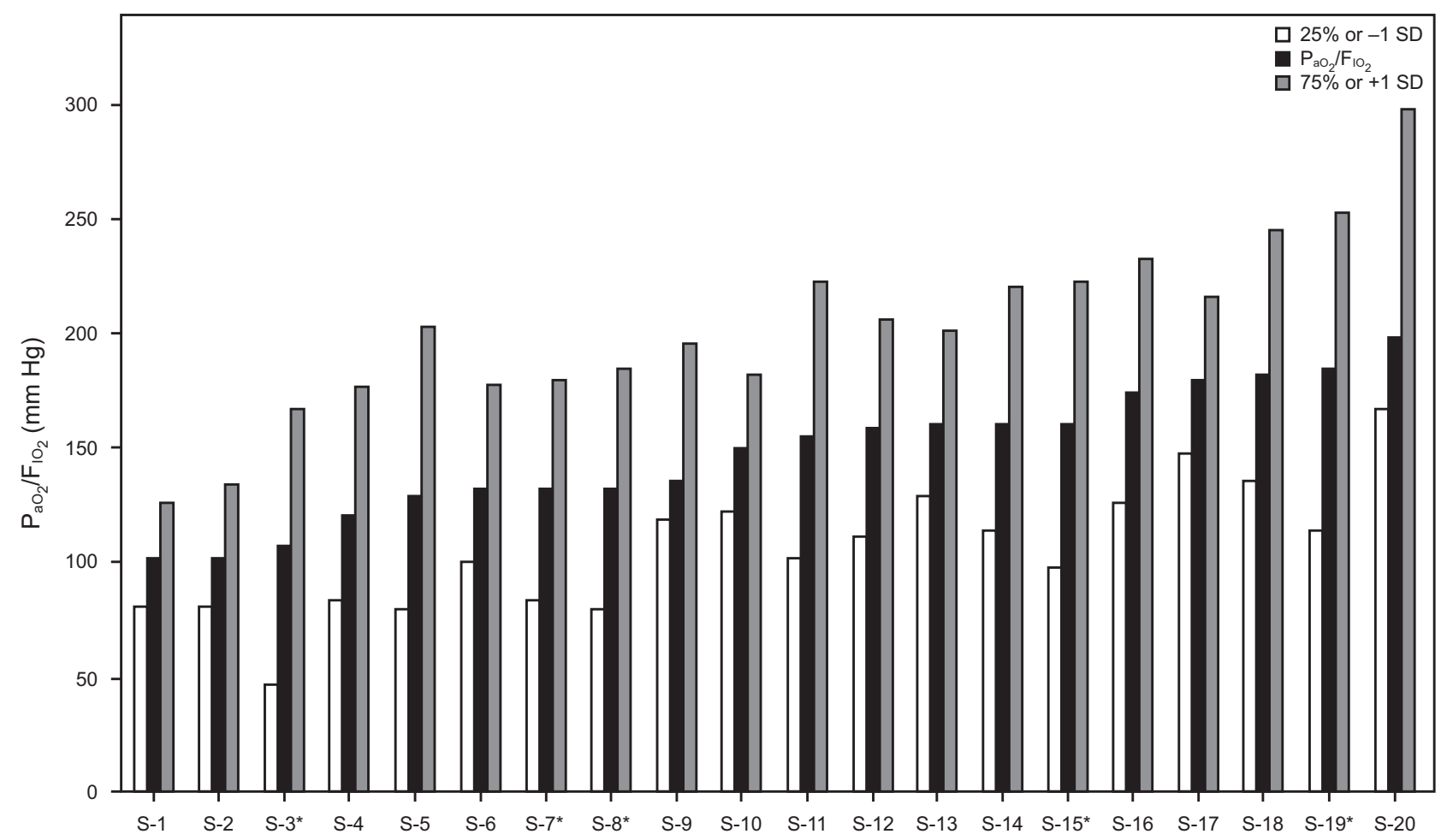

Fig. 4. Distribution of baseline (arterial oxygen tension-to inspired oxygen fraction) during invasive ventilation ordered from lowest to highest mean or median values (S denotes only the study order). Dispersion of values as either 1 SD above/below the mean or the 25 th/75th percentile.

$\mathrm{C}_{\mathrm{RS}}$, lung compliance, and chest wall compliance on the first day of invasive ventilation were 32,41 , and 154 $\mathrm{mL} / \mathrm{cm} \mathrm{H}_{2} \mathrm{O}$, respectively; these values were consistent with historical values reported in ARDS. ${ }^{152}$ The other study collected data within $48 \mathrm{~h}$ of intubation at a median PEEP of 10 (IQR 8-12) $\mathrm{cm} \mathrm{H}_{2} \mathrm{O} .{ }^{146}$ Although the median $\mathrm{C}_{\mathrm{RS}}$ (44 $\mathrm{mL} / \mathrm{cm} \mathrm{H}_{2} \mathrm{O}$ ) was higher than historical values, both median lung compliance and chest wall compliance (59 and $144 \mathrm{~mL} / \mathrm{cm} \mathrm{H}_{2} \mathrm{O}$, respectively) were consistent with corresponding historical values. On the basis of these limited data, pathologic alterations in both lung compliance and chest wall compliance in COVID-19 were similar to those reported in non-COVID-19-associated ARDS.

\section{Interplay of Oxygenation, PEEP, and Compliance}

In the early phase of COVID-19-associated ARDS, oxygenation fell within the Berlin definition boundaries of moderate ARDS with $\mathrm{P}_{\mathrm{aO}_{2}} / \mathrm{F}_{\mathrm{IO}_{2}}$ central tendencies across most studies of 101-198 $\mathrm{mm}$ Hg. ${ }^{67,69,106,107,110,113,115,116,120,127,140,141,144-148-150,152,153,157}$ Using the previously described lower and upper demarcation criteria, $40 \%$ of studies had $\mathrm{P}_{\mathrm{aO}_{2}} / \mathrm{F}_{\mathrm{IO}_{2}} \leq 100 \mathrm{~mm} \mathrm{Hg}$, whereas $55 \%$ had $\mathrm{P}_{\mathrm{aO}_{2}} / \mathrm{F}_{\mathrm{IO}_{2}}>200 \mathrm{~mm} \mathrm{Hg}$ (Figure 4).

The relevance of these data obviously is limited by the corresponding PEEP at these demarcated boundaries. For 16 studies that also reported PEEP data, there were 6 studies in which lower $\mathrm{P}_{\mathrm{aO}_{2}} / \mathrm{F}_{\mathrm{IO}_{2}}$ boundaries represented severe ARDS, and the corresponding PEEP boundaries were $7-11 \mathrm{~cm} \mathrm{H}_{2} \mathrm{O}$; in 5 of these studies PEEP boundaries were $<10 \mathrm{~cm} \mathrm{H}_{2} \mathrm{O} .{ }^{69,107,110,146,148,150}$ In 9 studies reporting upper $\mathrm{P}_{\mathrm{aO}} / \mathrm{F}_{\mathrm{IO}_{2}}$ boundaries representing mild ARDS, the corresponding PEEP boundaries were $12-18 \mathrm{~cm} \mathrm{H}_{2} \mathrm{O}$; in 8 of these studies these boundaries were $\geq 14 \mathrm{~cm}$ $\mathrm{H}_{2} \mathrm{O} .{ }^{106,113,115,116,122,127,141,144,149}$ The relationship between central tendencies of $\mathrm{P}_{\mathrm{aO}_{2}} / \mathrm{F}_{\mathrm{IO}_{2}}$ and PEEP across these studies showed a moderately high correlation $(\mathrm{r}=0.77[95 \%$ CI $0.56-0.88], P<.001$ ). This suggests initial oxygenation defects reported in COVID-19 mostly reflected how PEEP was being used rather than providing an accurate assessment of the underlying oxygenation defect. Moreover, it appears that PEEP levels required to stabilize oxygenation in COVID-19-associated ARDS are not different from those used in non-COVID-19-associated ARDS.

\section{Lung Recruitment Potential}

Lung recruitment potential in ARDS is multifactorial, with both limited application and variable efficacy. Efficacy depends more upon both the timing of recruitment relative to ARDS evolution (ie, early exudative vs later fibroproliferative phase) and the severity and distribution of lung injury (ie, diffuse vs lobar patterns) than on lung injury etiology. ${ }^{162}$ Five studies assessed recruitment potential in 
COVID-19-associated ARDS using a $10 \mathrm{~cm} \mathrm{H}_{2} \mathrm{O}$ increment or decrement in PEEP (see the supplementary materials at http://www.rcjournal.com). ${ }^{80,146,153,163,164}$

Four studies used the recruitment-to-inflation ratio (R/I) to assess recruitment potential. Briefly, immediately following the sudden application or withdrawal of PEEP, expired $V_{T}$ will decrease or increase, respectively, compared to prior breaths. This is because gas is either trapped by increased PEEP or released by decreased PEEP. The trapped or released volume represents changes in end-expiratory lung volume, so that recruitment compliance is calculated as expired $\Delta \mathrm{V} / \Delta \mathrm{PEEP}$. This value is compared to $\mathrm{C}_{\mathrm{RS}}$ measured at a PEEP of $5 \mathrm{~cm} \mathrm{H}_{2} \mathrm{O}$ (ie, compliance of the baby lung) on the basis of the assumption of linear $\mathrm{C}_{\mathrm{RS}}$ without changes in aerated lung units. ${ }^{165}$ The R/I validation study indicated that values $\geq 0.5$ were indicative of high recruitment potential, whereas values $<0.5$ indicated poor recruitment potential. ${ }^{165}$

Four studies assessing R/I in COVID-19 presented evenly divided results, each reporting either poor or good recruitment potential. Yet most studies noted a wide range of individual R/I values. ${ }^{146,153,164}$ Those with the lowest recruitment potential were studied in the fibroproliferative stage of ARDS and had extremely low mean $C_{R S}(20 \mathrm{~cm}$ $\left.\mathrm{H}_{2} \mathrm{O}\right) .{ }^{163}$ Similarly, Beloncle et al ${ }^{153}$ reported that when R/I was repeated $5 \mathrm{~d}$ later, $30 \%$ of those initially classified as having high recruitment potential had transitioned to low recruitment potential with a corresponding decline in $\mathrm{C}_{\mathrm{RS}}$.

Two of 5 studies that recorded $C_{R S}$ at each PEEP level observed that oxygenation and end-expiratory lung volume increased markedly at higher PEEP levels despite exhibiting both declining $\mathrm{C}_{\mathrm{RS}}$ and elevated stress index. ${ }^{80,164}$ This suggested recruitment occurred simultaneously with regional overdistention. Overall, the findings of recruitment potential in COVID-19-associated ARDS are consistent with those in non-COVID19-associated ARDS, specifically the timing of recruitment relative to ARDS onset. ${ }^{162}$

\section{Role of NIV in ARDS and Viral-Induced ARDS}

Managing ARDS with NIV is controversial as the syndrome itself independently predicts therapeutic failure, ${ }^{166}$ with overall intubation rates of $30-61 \%$ in some studies. ${ }^{104,166-172}$ In other studies, NIV failure rose with increasing ARDS severity from $19-22 \%$ (mild), 42-73\% (moderate), and $47-84 \%$ (severe). ${ }^{166,169,170}$ In addition, specific $\mathrm{P}_{\mathrm{aO}_{2}} / \mathrm{F}_{\mathrm{IO}_{2}}$ nodal points of $<150 \mathrm{~mm} \mathrm{Hg},{ }^{104,166,167,170,172}<175 \mathrm{~mm}$ $\mathrm{Hg},{ }^{168}$ and $\leq 179 \mathrm{~mm} \mathrm{Hg}^{169}$ are associated with NIV failure. NIV failure is strongly associated with multiple-organ system dysfunction reflected in elevated illness severity scores and septic shock. ${ }^{166-173}$ ARDS associated with viral pneumonia has produced mixed results. NIV failure in SARS CoV-1 was markedly lower (30-33\%) ${ }^{174-176}$ compared to influenza
A/B (44\%), ${ }^{173} \mathrm{H} 1 \mathrm{~N} 1$ (59-85\%), ${ }^{177-180}$ and MERS (92\%). ${ }^{181}$ During COVID-19, a national database study reported NIV failure of $49 \% .^{125}$

\section{Role of NIV in COVID-19}

In China, where the initial treatment approach to COVID-19 favored NIV, ${ }^{11}$ an early nationwide study reported that NIV accounted for $87 \%$ of all mechanical ventilation with a substantially lower failure rate of $25 \%$ and an associated mortality rate of $17 \%$ (compared to $50 \%$ in those requiring invasive ventilation). ${ }^{121} \mathrm{~A}$ similar study from Wuhan also reported higher initial NIV usage (57\%) with associated mortality of $41 \%$ versus $92 \%$ in patients requiring invasive ventilation. ${ }^{24}$

Specific NIV studies in COVID-19 largely focused on the use of CPAP in the non-ICU setting (Table 3). ${ }^{182-195}$ Unfortunately $46 \%$ of these were research letters and often lacked pertinent data. ${ }^{182-187}$ Nonetheless, $71 \%$ of all studies reported relatively low failure rates of $11-28 \%$ and relatively low associated mortality among those without care limitations $(\leq 30 \%){ }^{153,182-184,186,190,192}$ This was accomplished mostly with moderate $\mathrm{CPAP}\left(\leq 12 \mathrm{~cm} \mathrm{H}_{2} \mathrm{O}\right)$. However, these results were often accompanied either by low, vague thresholds for escalating care from low-level oxygen therapy (eg, supplemental $\mathrm{O}_{2}>6 \mathrm{~L} / \mathrm{min}$ to maintain $\left.>92 \%\right)^{182,185}$ or provided no documentation whatsoever. ${ }^{184,187,195}$

In 8 traditional observational studies, failure rates were $17-57 \%$ with associated mortality rates of $22-97 \% .^{188-195} \mathrm{In}$ some studies, substantially higher mortality rates were reported in subjects in whom pre-NIV $\mathrm{P}_{\mathrm{aO}} / \mathrm{F}_{\mathrm{IO}_{2}}$ was $<150$ $\mathrm{mm} \mathrm{Hg}(53 \%)^{188}$ or subjects who had care limitations in place $(55-72 \%){ }^{186,189,194}$

NIV duration was reported in $50 \%$ of studies with median values of 5-6 d. ${ }^{182,189}$ In some studies, median duration was 3-8 d when therapy was successful compared to $0.7-8$ $\mathrm{d}$ in subjects who required intubation and $1.8 \mathrm{~d}$ in those with care limitations in place. ${ }^{184}$

Risk factors associated with NIV failure included increased age, ${ }^{185,188,189,194,195}$ admission Sequential Organ Failure Assessment (SOFA) score, ${ }^{184,192,195}$ Severe Acute Physiology Score (SAPS III), ${ }^{195}$ vasopressor use,${ }^{195}$ renal replacement therapy, ${ }^{195}$ and number of comorbidities. ${ }^{189,192}$ Likewise, increased levels of C-reactive protein, ${ }^{186,188,194}$ interleukin- $6{ }^{186}$ lactate dehydrogenase, ${ }^{189} d$-dimers, ${ }^{185}$ and decreased platelet levels ${ }^{188}$ were also associated with NIV failure. Together these signify marked inflammation often observed in multiple-organ system dysfunction, endothelial dysfunction, pulmonary hypertension, and a procoagulant state.

Pulmonary-related variables associated with NIV failure included severity of pneumonia at hospital admission, ${ }^{186}$ decreased time to oxygen therapy failure (particularly when it resulted in $\left.\mathrm{P}_{\mathrm{aO}_{2}} / \mathrm{F}_{\mathrm{IO}_{2}}<150 \mathrm{~mm} \mathrm{Hg}\right){ }^{189}$ and hyperpnea (ie, median minute ventilation of $15.8 \mathrm{~L} / \mathrm{min}$ corresponding 
Mechanical Ventilation During the First Year of COVID-19

Table 3. Noninvasive Ventilation Usage and Outcomes

\begin{tabular}{|c|c|c|c|}
\hline Study & NIV Evaluation & NIV Failure & NIV/CPAP \\
\hline $\begin{array}{l}\text { Brusasco et al }{ }^{183} \\
\text { Single center } \\
\text { General ward/COVID unit } \\
N=64\end{array}$ & $\begin{array}{l}\text { Venti mask } \mathrm{F}_{\mathrm{IO}_{2}} 0.50 \\
\text { Hypoxemia: } \mathrm{P} / \mathrm{F}<200 \mathrm{~mm} \mathrm{Hg} \\
\text { Baseline: } \mathrm{P} / \mathrm{F} 119(99-153) \mathrm{mm} \mathrm{Hg}\end{array}$ & $\begin{array}{l}\text { Intubation: } 11 \% \\
\text { Mortality: } 6 \%\end{array}$ & $\begin{array}{l}\text { CPAP: } 10 \mathrm{~cm} \mathrm{H}_{2} \mathrm{O} \\
\text { Treatment duration: NR } \\
\text { Time to NIV failure: NR }\end{array}$ \\
\hline $\begin{array}{l}\text { Di Domenico et al }{ }^{194} \\
\text { Single center } \\
\text { General ward/COVID unit } \\
N=90\end{array}$ & $\begin{array}{l}\mathrm{O}_{2} \text { mask } 12 \mathrm{~L} / \mathrm{min} \\
\mathrm{S}_{\mathrm{pO}_{2}}<90 \% \\
\text { Hypoxemia P/F: } 248 \pm 17 \mathrm{~mm} \mathrm{Hg} \\
\text { DNR/DNI baseline P/F: } 186 \pm \\
\quad 20 \mathrm{~mm} \mathrm{Hg}\end{array}$ & $\begin{array}{l}\text { Unrestricted care: } \\
\text { Intubation: } 57 \% \\
\text { Mortality: } 47 \% \\
\text { DNR/DNI care: } \\
\text { Mortality: } 89 \%\end{array}$ & $\begin{array}{l}\text { Parameters: NR } \\
\text { Treatment duration: NR } \\
\text { Time to NIV failure: }<1 \mathrm{~d}\end{array}$ \\
\hline $\begin{array}{l}\text { Gaulton et } \mathrm{a}^{187} \\
\text { Multicenter } \\
\text { ICU } \\
N=59^{* \dagger}\end{array}$ & $\begin{array}{l}\text { NR } \\
\text { NR } \\
\text { NR }\end{array}$ & $\begin{array}{l}\text { Intubation: } 18 \% \\
\text { Mortality: NR }\end{array}$ & $\begin{array}{l}\text { CPAP: } 11 \pm 2 \mathrm{~cm} \mathrm{H}_{2} \mathrm{O} \\
\text { Treatment duration: } \mathrm{NR}\end{array}$ \\
\hline $\begin{array}{l}\text { Oranger et al }{ }^{182} \\
\text { Single center } \\
\text { General ward/COVID unit } \\
N=38\end{array}$ & $\begin{array}{l}\mathrm{NR} \\
\mathrm{O}_{2}>6 \mathrm{~L} / \text { min to keep } \mathrm{S}_{\mathrm{pO}_{2}}>92 \% \\
\mathrm{NR}\end{array}$ & $\begin{array}{l}\text { Intubation: } 24 \% \\
\text { Mortality: } 0 \%\end{array}$ & $\begin{array}{l}\text { CPAP: } 10(8-12) \mathrm{cm} \mathrm{H}_{2} \mathrm{O} \\
\text { Treatment duration: } 5(2-8) \mathrm{d} \text {, } \\
\quad 8(4-11) \mathrm{h} / \mathrm{d}\end{array}$ \\
\hline $\begin{array}{l}\text { Sivaloganathan et } \mathrm{al}^{184} \\
\text { Single center } \\
\text { ICU, General ward/COVID unit } \\
N=58\end{array}$ & $\begin{array}{l}\mathrm{NR} \\
\mathrm{NR} \\
\mathrm{NR}\end{array}$ & $\begin{array}{l}\text { Intubation: } 47 \% \\
\text { Mortality: } 14 \% \\
\text { DNR/DNI care: } \\
\text { Mortality } 83 \%\end{array}$ & $\begin{array}{l}\text { CPAP: NR } \\
\text { Treatment duration: } \\
\text { No intubation: } 72(41-132) \mathrm{h} \\
\text { Time to intubation: } 17(4-31) \mathrm{h} \\
55 \% \text { failure } \leq 24 \mathrm{~h} \\
\text { DNI: } 44(8-103) \mathrm{h}\end{array}$ \\
\hline $\begin{array}{l}\text { Avdeev et } \mathrm{al}^{185} \\
\text { Multicenter } \\
\text { General ward/COVID unit } \\
N=61\end{array}$ & $\begin{array}{l}\mathrm{NR} \\
\mathrm{O}_{2}>6 \mathrm{~L} / \mathrm{min} \text { to keep } \mathrm{S}_{\mathrm{pO}_{2}}>92 \% \\
\text { Baseline P/F: } 164(131-200) \mathrm{mm} \mathrm{Hg}\end{array}$ & $\begin{array}{l}\text { Intubation: } 28 \% \\
\text { Mortality: } 88 \%\end{array}$ & $\begin{array}{l}\text { CPAP }(74 \%): 10(10-12) \mathrm{cm} \mathrm{H}_{2} \mathrm{O} \\
\Delta \text { PS/PEEP }(26 \%): 10(8-12) / \\
10(10-13) \mathrm{cm} \mathrm{H}_{2} \mathrm{O} \\
\text { Treatment duration: } \\
\text { No intubation: } 8(6-11) \mathrm{d} \\
\text { Time to intubation: } 3(3-8) \mathrm{d}\end{array}$ \\
\hline $\begin{array}{l}\text { Aliberti et al }{ }^{186} \\
\text { Multicenter } \\
\text { General ward/COVID unit } \\
N=157^{*}\end{array}$ & $\begin{array}{l}\text { Venti mask } \mathrm{F}_{\mathrm{IO}_{2}} \geq 0.50 \text { or NRM } \\
\text { Hypoxemia P/F: }<300 \mathrm{~mm} \mathrm{Hg} \\
\text { Baseline P/F: } 143(97-203) \mathrm{mm} \mathrm{Hg}\end{array}$ & $\begin{array}{l}\text { Unrestricted care: } \\
\text { Intubation: } 22 \% \\
\text { Mortality: } 26 \% \\
\text { DNI/DNR care } \\
\text { Mortality: } 55 \%\end{array}$ & $\begin{array}{l}\text { CPAP: } 11 \pm 2 \mathrm{~cm} \mathrm{H}_{2} \mathrm{O} \\
\mathrm{F}_{\mathrm{IO}_{2}}: 0.6(0.5-0.6) \\
\text { Treatment duration: } \\
\quad \text { Success: } 7(4-12) \mathrm{d} \\
\text { Failure: } 7(1-8) \mathrm{d} \\
\text { Time to intubation: } 3(2-5) \mathrm{d}\end{array}$ \\
\hline $\begin{array}{l}\text { Bellani et al }{ }^{188} \\
\text { Multicenter } \\
\text { General ward/COVID unit, ICU } \\
N=798^{*}\end{array}$ & $\begin{array}{l}\text { NR } \\
\text { NR } \\
\text { Baseline P/F: } 168 \pm 98 \mathrm{~mm} \mathrm{Hg}\end{array}$ & $\begin{array}{l}\text { Intubation: } 17 \% \\
\text { Mortality without intubation: } 22 \% \\
\text { Mortality when initial } \\
\qquad \mathrm{P} / \mathrm{F}<150 \mathrm{~mm} \mathrm{Hg}: 53 \%\end{array}$ & $\begin{array}{l}85 \% \text { CPAP: } 11 \pm 3 \mathrm{~cm} \mathrm{H}_{2} \mathrm{O} \\
10 \% \text { NIV (data NR) } \\
\text { Treatment duration: NR } \\
\text { Admit to NIV: } 1(0-4) \mathrm{d} \\
\text { Time to intubation: } 8(5-13) \mathrm{d}\end{array}$ \\
\hline $\begin{array}{l}\text { Coppadoro et al }{ }^{189} \\
\text { Multicenter } \\
\text { General ward/COVID unit } \\
N=303^{*}\end{array}$ & $\begin{array}{l}\text { NRM } \\
\text { NR } \\
\text { P/F } 103(79-176) \mathrm{mm} \mathrm{Hg}\end{array}$ & $\begin{array}{l}\text { Unrestricted care: } \\
\text { Intubation: } 31 \% \\
\text { Mortality: } 41 \% \\
\text { DNI/DNR care } \\
\text { Mortality: } 72 \%\end{array}$ & $\begin{array}{l}\text { CPAP: } 10 \text { (7-10) } \\
\text { Treatment duration: } 6 \text { (3-9) d, } 21 \\
\text { h/d } \\
\text { Admit to NIV: } 1(0-2) \text { d }\end{array}$ \\
\hline
\end{tabular}

(Continued) 
Table 3. Continued

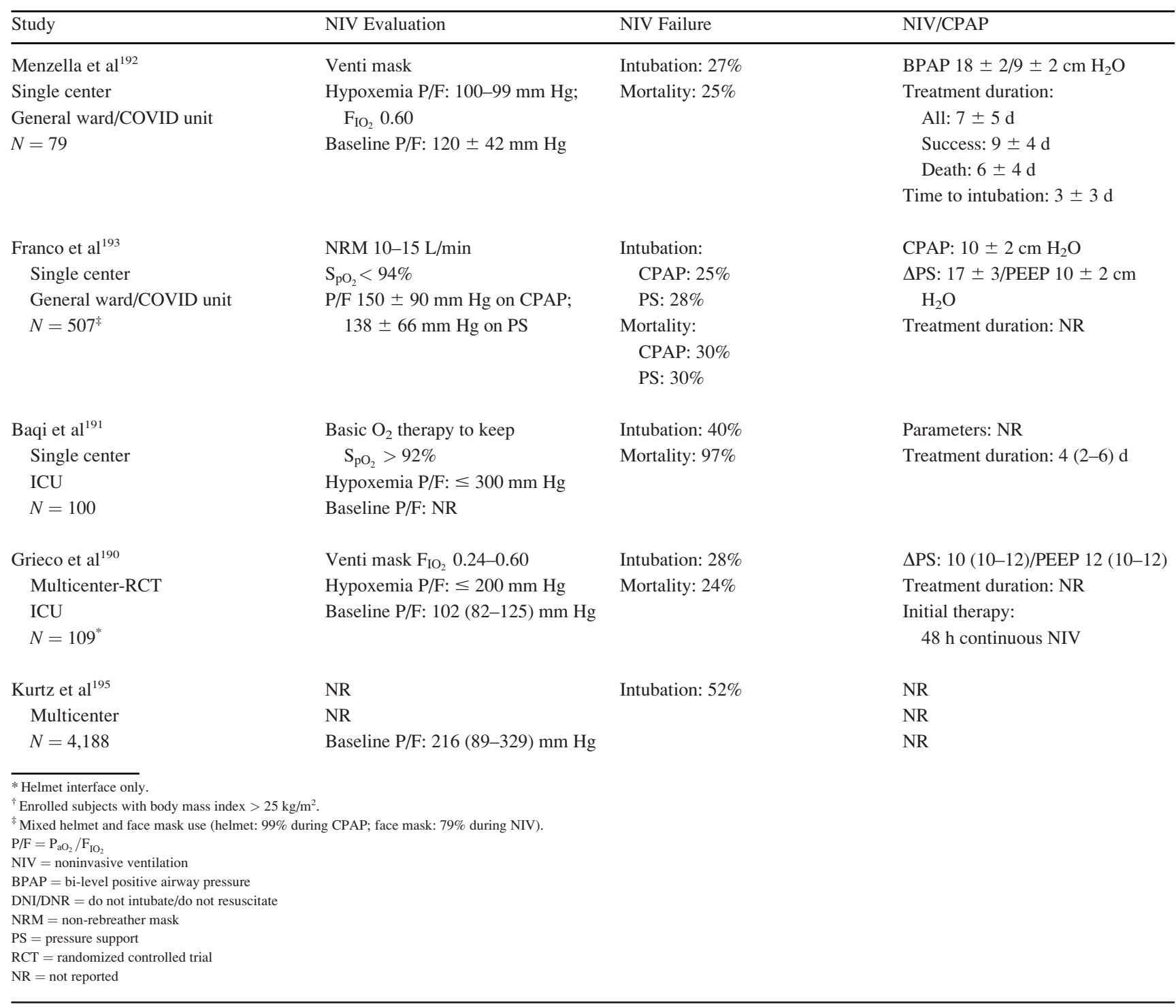

with median of $41.5 \mathrm{~mm} \mathrm{Hg}) .{ }^{185}$ Despite the general association between low $\mathrm{P}_{\mathrm{aO}} / \mathrm{F}_{\mathrm{IO}_{2}}$ and NIV failure, some studies revealed that neither baseline values ${ }^{185}$ nor a cutoff of $<$ $150 \mathrm{~mm} \mathrm{Hg}$ were predictive. ${ }^{183}$ Nonetheless, larger studies affirmed the predictive value when $\mathrm{P}_{\mathrm{aO}_{2}} / \mathrm{F}_{\mathrm{IO}_{2}}$ was $<150$ mm Hg. ${ }^{188,189}$ Successful NIV therapy was characterized by marked improvement in $\mathrm{P}_{\mathrm{aO}_{2}} / \mathrm{F}_{\mathrm{IO}_{2}}$ and decreased breathing frequency after initiation (particularly $<30$ breaths/min) along with sustained $\mathrm{P}_{\mathrm{aO}_{2}} / \mathrm{F}_{\mathrm{IO}_{2}}>150 \mathrm{~mm} \mathrm{Hg}$ over the course of therapy. ${ }^{189}$

The characteristics of NIV use and outcomes in COVID19-associated ARDS appear to be similar to those observed in non-COVID-19-associated ARDS in terms of the main drivers of therapeutic failure: (1) poor baseline oxygenation (and absence of sustained improvement with therapy), (2) comorbidities, and (3) illness severity and the presence of multiple-organ system dysfunction. The fact that several of these factors also drive mortality during invasive ventilation should be considered when judging the relative efficacy of either therapy.

\section{Risk of Health Care Provider Cross-Infection During NIV}

Only a few studies reported health care provider infection data. $^{182,183,185,193}$ Two studies reported no infections when health care providers had access to the full range of personal protective equipment and when environmental controls were in place. ${ }^{183,185}$ Another study reported only that COVID-19 infection rates among health care providers increased from 
$6 \%$ to $10 \%$ after implementing NIV (the only detail provided was that bacterial filters were placed on the expiratory limb of the circuit). ${ }^{182}$ The most detailed information was provided by a study from Lombardy, Italy during the initial wave when hospital resources were extremely limited. Despite the availability of personal protective equipment, health care provider infection rate was high (11.5\%) and corresponded to a lack of negative pressure rooms for conducting NIV therapy. ${ }^{193}$

During the 2003 SARS Co-V-1 pandemic, health care provider infection occurred primarily prior to identification of the highly contagious virus as the source and, therefore, prior to instituting protective measures. ${ }^{27,132,196,197}$ When health care providers were given access to the full range of personal protective equipment (along with stringent environmental controls), there was no further incidence of cross-infection. ${ }^{174,198}$

\section{Summary}

It was perhaps inevitable that COVID-19 would rekindle the long, contentious debate over what constitutes ARDS and its management. This issue dates back to the mid-1970s with Dr Petty's "confessions of a lumper"1 and has continued throughout the history of ARDS, reflected in the need to develop a lung injury score, ${ }^{199}$ the American European Consensus Conference definition, ${ }^{200}$ and the Berlin definition. ${ }^{38}$ In the aftermath of COVID-19, it is quite possible that the definition of ARDS will be reexamined and perhaps modified to adjust for how specific viral pathogens might alter the progression of acute lung injury. The unanticipated pathophysiologic effects of the way in which SARS Co-V utilizes the ACE II receptor to infect pulmonary tissue stands as an important lesson to be incorporated into our understanding of ARDS.

In answer to the controversies that animated the early months of the pandemic, the vast majority of patients with COVID-19 who required invasive ventilation ultimately presented with ARDS. This is supported by its viral etiology, its histopathologic pattern and evolution, radiographic presentation and evolution, PEEP requirements, severity of hypoxemia, compliance, recruitment potential, duration of invasive ventilation, and responsiveness to NIV. All of these characteristics are uniformly consistent with non-COVID-19-associated ARDS. With regard to mortality associated with invasive ventilation in COVID-19, the majority of studies reported it to be within or below that reported in the general ARDS population.

\section{REFERENCES}

1. Petty TL. Editorial: the adult respiratory distress syndrome (confessions of a “lumper"). Am Rev Respir Dis 1975;111(6):713-715.
2. Rubenfeld GD. Is SARS just ARDS? JAMA 2003;290(3):397-399.

3. Bakewell S. How to live: or a life of Montaigne. New York: Other Press; 2010:128.

4. Tobin MJ. The criteria used to justify endotracheal intubation of patients with COVID-19 are worrisome. Can J Anaesth 2021;68 (2):258-259.

5. Tobin MJ, Jubran A, Laghi F. Hypoxaemia does not necessitate tracheal intubation in COVID-19 patients. Br J Anaesth 2021;126(2): e75-e76.

6. Tobin MJ. Does making a diagnosis of ARDS in patients with coronavirus disease 2019 matter? Chest 2020;158(6):2275-2277.

7. Gattinoni L, Chiumello D, Caironi P, Busana M, Romitti F, Brazzi L, et al. COVID-19 pneumonia: different respiratory treatments for different phenotypes? Intensive Care Med 2020;46(6):1099-1102.

8. Gattinoni L, Chiumello D, Rossi S. COVID-19 pneumonia: ARDS or not? Crit Care 2020;24(1):154.

9. Honore PM, Barreto Gutierrez L, Kugener L, Redant S, Attou R, Gallerani A, et al. Compared to NIPPV, HFNC is more dangerous regarding aerosol dispersion and contamination of healthcare personnel: we are not sure. Crit Care 2020;24(1):482.

10. Remy KE, Lin JC, Verhoef PA. High-flow nasal cannula may be no safer than non-invasive positive pressure ventilation for COVID-19 patients. Crit Care 2020;24(1):169.

11. Cerceo E, Fraimow H. Lessons learned from the front line: outcomes of noninvasive ventilation for coronavirus disease 2019 pneumonia in China. Crit Care Med 2020;48(9):1400-1402.

12. Macintyre CR, Seale H, Yang P, Zhang Y, Shi W, Almatroudi A, et al. Quantifying the risk of respiratory infection in healthcare workers performing high-risk procedures. Epidemiol Infect 2014;142 (9): $1802-1808$.

13. Wu Z, McGoogan JM. Characteristics of and important lessons from the coronavirus disease 2019 (COVID-19) outbreak in China: summary of a report of 72,314 cases from the Chinese Center for Disease Control and Prevention. JAMA 2020;323(13):1239-1242.

14. Niederman MS, Richeldi L, Chotirmall SH, Bai C. Rising to the challenge of COVID-19: advice for pulmonary and critical care and an agenda for research. Am J Respir Crit Care Med 2020;201(9):10191022.

15. Marini JJ, Gattinoni L. Management of COVID-19 respiratory distress. JAMA 2020;323(22):2329-2330.

16. Gattinoni L, Marini JJ, Busana M, Chiumello D, Camporota L. Spontaneous breathing, transpulmonary pressure and mathematical trickery. Ann Intensive Care 2020;10(1):88.

17. Li YC, Bai WZ, Hashikawa T. The neuroinvasive potential of SARSCoV2 may play a role in the respiratory failure of COVID-19 patients. J Med Virol 2020;92(6):552-555.

18. Meng L, Qiu H, Wan L, Ai Y, Xue Z, Guo Q, et al. Intubation and ventilation amid the COVID-19 outbreak: Wuhan's experience. Anesthesiology 2020;132(6):1317-1332.

19. Filipovic N, Saveljic I, Hamada K, Tsuda A. Abrupt deterioration of COVID-19 patients and spreading of SARS COV-2 virions in the lungs. Ann Biomed Eng 2020;48(12):2705-2706.

20. Rello J, Storti E, Belliato M, Serrano R. Clinical phenotypes of SARS-CoV-2: implications for clinicians and researchers. Eur Respir J 2020;55(5):2001028.

21. Savel RH, Shiloh AL, Saunders PC, Kupfer Y. Mechanical ventilation during the coronavirus disease 2019 pandemic: combating the tsunami of misinformation from mainstream and social media. Crit Care Med 2020;48(9):1398-1400.

22. Bahl A, Van Baalen MN, Ortiz L, Chen NW, Todd C, Milad M, et al. Early predictors of in-hospital mortality in patients with COVID-19 in a large American cohort. Intern Emerg Med 2020;15(8):14851499. 


\section{Mechanical Ventilation During the First Year of COVID-19}

23. Zhou F, Yu T, Du R, Fan G, Liu Y, Liu Z, et al. Clinical course and risk factors for mortality of adult inpatients with COVID-19 in Wuhan, China: a retrospective cohort study. Lancet 2020;395 (10229):1054-1062.

24. Hua J, Qian C, Luo Z, Li Q, Wang F. Invasive mechanical ventilation in COVID-19 patient management: the experience with 469 patients in Wuhan. Crit Care 2020;24(1):348.

25. Chen T, Wu D, Chen H, Yan W, Yang D, Chen G, et al. Clinical characteristics of 113 deceased patients with coronavirus disease 2019: retrospective study. BMJ 2020;368:m1091.

26. Swenson KE, Ruoss SJ, Swenson ER. The pathophysiology and dangers of silent hypoxemia in COVID-19 lung injury. Ann Am Thorac Soc 2021 [Epub ahead of print].

27. Raboud J, Shigayeva A, McGeer A, Bontovics E, Chapman M, Gravel D, et al. Risk factors for SARS transmission from patients requiring intubation: a multicentre investigation in Toronto, Canada. PLoS One 2010;5(5):e10717.

28. Bryson B. A short history of nearly everything. New York: Broadway Books; 2003:363.

29. Li X, Ma X. Acute respiratory failure in COVID-19: is it "typical" ARDS? Crit Care 2020;24(1):198.

30. Luks AM, Freer L, Grissom CK, McIntosh SE, Schoene RB, Swenson ER, et al. COVID-19 lung injury is not high altitude pulmonary edema. High Alt Med Biol 2020;21(2):192-193.

31. Ashbaugh DG, Bigelow DB, Petty TL, Levine BE. Acute respiratory distress in adults. Lancet 1967;290(7511):319-323.

32. Barry J. The great influenza: the epic story of the deadliest plague in history. New York: Viking; 2004:250-252.

33. Huang C, Wang Y, Li X, Ren L, Zhao J, Hu Y, et al. Clinical features of patients infected with 2019 novel coronavirus in Wuhan, China. Lancet 2020;395(10223):497-506.

34. Yang X, Yu Y, Xu J, Shu H, Xia J, Liu H, et al. Clinical course and outcomes of critically ill patients with SARS-CoV-2 pneumonia in Wuhan, China: a single-centered, retrospective, observational study. Lancet Respir Med 2020;8(5):475-481.

35. Rubenfeld GD, Caldwell E, Granton J, Hudson LD, Matthay MA. Interobserver variability in applying a radiographic definition for ARDS. Chest 1999;116(5):1347-1353.

36. Tsolaki V, Siempos I, Magira E, Kokkoris S, Zakynthinos GE, Zakynthinos S. PEEP levels in COVID-19 pneumonia. Crit Care 2020;24(1):303.

37. Ferguson ND, Frutos-Vivar F, Esteban A, Fernandez-Segoviano P, Aramburu JA, Najera L, et al. Acute respiratory distress syndrome: underrecognition by clinicians and diagnostic accuracy of three clinical definitions. Crit Care Med 2005;33(10):2228-2234.

38. ARDS Definition Task Force, Ranieri VM, Rubenfeld GD, Thompson BT, Ferguson ND, Caldwell E, et al. Acute respiratory distress syndrome: the Berlin Definition. JAMA 2012;307(23):25262533.

39. Hudson LD, Milberg JA, Anardi D, Maunder RJ. Clinical risks for development of the acute respiratory distress syndrome. Am J Respir Crit Care Med 1995;151(2 Pt 1):293-301.

40. Brower RG, Lanken PN, MacIntyre N, Matthay MA, Morris A, Ancukiewicz M, et al. Higher versus lower positive end-expiratory pressures in patients with the acute respiratory distress syndrome. $\mathrm{N}$ Engl J Med 2004;351(4):327-336.

41. Acute Respiratory Distress Syndrome Network, Brower RG, Matthay MA, Morris A, Schoenfeld D, Thompson BT, et al. Ventilation with lower tidal volumes as compared with traditional tidal volumes for acute lung injury and the acute respiratory distress syndrome. N Engl J Med 2000;342(18):1301-1308

42. Writing Group for the Alveolar Recruitment for Acute Respiratory Distress Syndrome Trial Investigators, Cavalcanti AB, Suzumura EA, Laranjeira LN, Paisani DM, Damiani LP, et al. Effect of lung recruitment and titrated positive end-expiratory pressure (PEEP) vs low PEEP on mortality in patients with acute respiratory distress syndrome: a randomized clinical trial. JAMA 2017;318(14):1335-1345.

43. Meade MO, Cook DJ, Guyatt GH, Slutsky AS, Arabi YM, Cooper DJ, et al. Ventilation strategy using low tidal volumes, recruitment maneuvers, and high positive end-expiratory pressure for acute lung injury and acute respiratory distress syndrome: a randomized controlled trial. JAMA 2008;299(6):637-645.

44. Mercat A, Richard JC, Vielle B, Jaber S, Osman D, Diehl JL, et al. Positive end-expiratory pressure setting in adults with acute lung injury and acute respiratory distress syndrome: a randomized controlled trial. JAMA 2008;299(6):646-655.

45. Bos LDJ, Sinha P, Dickson RP. Response to COVID-19 phenotyping correspondence. Eur Respir J 2020;56(2):2002756.

46. Bos LDJ, Sinha P, Dickson RP. The perils of premature phenotyping in COVID-19: a call for caution. Eur Respir J 2020;56(1):2001768.

47. Gattinoni L, Camporota L, Marini JJ. COVID-19 phenotypes: leading or misleading? Eur Respir J 2020;56(2):2002195.

48. Rajendram R. Building the house of CARDS by phenotyping on the fly. Eur Respir J 2020;56(2):2002429.

49. Cherian R, Chandra B, Tung ML, Vuylsteke A. COVID-19 conundrum: clinical phenotyping based on pathophysiology as a promising approach to guide therapy in a novel illness. Eur Respir J 2020;56 (2):2002135.

50. Jain A, Doyle DJ. Stages or phenotypes? A critical look at COVID19 pathophysiology. Intensive Care Med 2020;46(7):1494-1495.

51. Henderson LA, Canna SW, Schulert GS, Volpi S, Lee PY, Kernan $\mathrm{KF}$, et al. On the alert for cytokine storm: immunopathology in COVID-19. Arthritis Rheumatol 2020;72(7):1059-1063.

52. Alharthy A, Faqihi F, Memish ZA, Karakitsos D. Lung injury in COVID-19: an emerging hypothesis. ACS Chem Neurosci 2020;11 (15):2156-2158.

53. Kallet RH, Matthay MA. Hyperoxic acute lung injury. Respir Care 2013;58(1):123-141

54. Ngiam N, Kavanagh BP. Ventilator-induced lung injury: the role of gene activation. Curr Opin Crit Care 2012;18(1):16-22.

55. Calfee CS, Delucchi K, Parsons PE, Thompson BT, Ware LB, Matthay MA. Subphenotypes in acute respiratory distress syndrome: latent class analysis of data from two randomised controlled trials. Lancet Respir Med 2014;2(8):611-620.

56. Famous KR, Delucchi K, Ware LB, Kangelaris KN, Liu KD, Thompson BT, et al. Acute respiratory distress syndrome subphenotypes respond differently to randomized fluid management strategy. Am J Respir Crit Care Med 2017;195(3):331-338.

57. Lin SZ, Zhou D, Zhou F. Coronavirus disease 2019 (COVID-19): cytokine storms, hyper-inflammatory phenotypes, and acute respiratory distress syndrome. Genes Dis 2020;7:520-527.

58. Gattinoni L, Coppola S, Cressoni M, Busana M, Rossi S, Chiumello D. COVID-19 does not lead to a "typical" acute respiratory distress syndrome. Am J Respir Crit Care Med 2020;201(10):1299-1300.

59. Raurich JM, Vilar M, Colomar A, Ibanez J, Ayestaran I, PerezBarcena J, et al. Prognostic value of the pulmonary dead-space fraction during the early and intermediate phases of acute respiratory distress syndrome. Respir Care 2010;55(3):282-287.

60. Nunes S, Valta P, Takala J. Changes in respiratory mechanics and gas exchange during the acute respiratory distress syndrome. Acta Anaesthesiol Scand 2006;50(1):80-91.

61. Ranieri VM, Suter PM, Tortorella C, De Tullio R, Dayer JM, Brienza A, et al. Effect of mechanical ventilation on inflammatory mediators in patients with acute respiratory distress syndrome: a randomized controlled trial. JAMA 1999;282(1):54-61.

62. Esteban A, Alía I, Gordo F, de Pablo R, Suarez J, González G, Blanco J. Prospective randomized trial comparing pressure-controlled ventilation and volume-controlled ventilation in ARDS. For 


\section{Mechanical Ventilation During the First Year of COVID-19}

the Spanish Lung Failure Collaborative Group. Chest 2000;117 (6): 1690-1696.

63. Bellani G, Laffey JG, Pham T, Fan E, Brochard L, Esteban A, et al. Epidemiology, patterns of care, and mortality for patients with acute respiratory distress syndrome in intensive care units in 50 countries. JAMA 2016;315(8):788-800.

64. Chiumello D, Cressoni M, Carlesso E, Caspani ML, Marino A, Gallazzi E, et al. Bedside selection of positive end-expiratory pressure in mild, moderate, and severe acute respiratory distress syndrome. Crit Care Med 2014;42(2):252-264.

65. Gernoth C, Wagner G, Pelosi P, Luecke T. Respiratory and haemodynamic changes during decremental open lung positive end-expiratory pressure titration in patients with acute respiratory distress syndrome. Crit Care 2009;13(2):R59.

66. Gattinoni L, Caironi P, Cressoni M, Chiumello D, Ranieri VM, Quintel M, et al. Lung recruitment in patients with the acute respiratory distress syndrome. N Engl J Med 2006;354(17):1775-1786.

67. Chiumello D, Busana M, Coppola S, Romitti F, Formenti P, Bonifazi $\mathrm{M}$, et al. Physiological and quantitative CT-scan characterization of COVID-19 and typical ARDS: a matched cohort study. Intensive Care Med 2020;46(12):2187-2196.

68. Alhazzani W, Møller MH, Arabi YM, Loeb M, Gong MN, Fan E, et al. Surviving Sepsis Campaign: guidelines on the management of critically ill adults with coronavirus disease 2019 (COVID-19). Crit Care Med 2020;48(6):e440-e469.

69. Bos LDJ. COVID-19-related acute respiratory distress syndrome: not so atypical. Am J Respir Crit Care Med 2020;202(4):622-624.

70. Tobin MJ. Culmination of an era in research on the acute respiratory distress syndrome. N Engl J Med 2000;342(18):1360-1361.

71. Kallet RH, Campbell AR, Dicker RA, Katz JA, Mackersie RC. Effects of tidal volume on work of breathing during lung-protective ventilation in patients with acute lung injury and acute respiratory distress syndrome. Crit Care Med 2006;34(1):8-14.

72. Fan E, Beitler JR, Brochard L, Calfee CS, Ferguson ND, Slutsky AS, et al. COVID-19-associated acute respiratory distress syndrome: is a different approach to management warranted? Lancet Respir Med 2020;8(8):816-821.

73. Rice TW, Janz DR. In defense of evidence-based medicine for the treatment of COVID-19 acute respiratory distress syndrome. Ann Am Thorac Soc 2020;17(7):787-789.

74. Kollef MH, Levy NT, Ahrens TS, Schaiff R, Prentice D, Sherman G. The use of continuous i.v. sedation is associated with prolongation of mechanical ventilation. Chest 1998;114(2):541-548.

75. Jones C, Bäckman C, Capuzzo M, Flaatten H, Rylander C, Griffiths RD. Precipitants of post-traumatic stress disorder following intensive care: a hypothesis generating study of diversity in care. Intensive Care Med 2007;33(6):978-985.

76. Wade DM, Howell DC, Weinman JA, Hardy RJ, Mythen MG, Brewin CR, et al. Investigating risk factors for psychological morbidity three months after intensive care: a prospective cohort study. Crit Care 2012;16(5):R192.

77. Epstein SK. How often does patient-ventilator asynchrony occur and what are the consequences? Respir Care 2011;56(1):25-38.

78. Martos-Benitez FD, Dominguez-Valdes Y, Burgos-Araguez D, Larrondo-Muguercia H, Orama-Requejo V, Lara-Ponce KX, et al. Outcomes of ventilatory asynchrony in patients with inspiratory effort. Rev Bras Ter Intensiva 2020;32(2):284-294.

79. Tabone L, Martin S, Emeriaud G. Positive end-expiratory pressure in coronavirus disease 2019 acute respiratory distress syndrome: higher may be too high. Crit Care Med 2020;48(12):1925-1927.

80. Grasso S, Mirabella L, Murgolo F, Di Mussi R, Pisani L, Dalfino L, et al. Effects of positive end-expiratory pressure in "high compliance" severe acute respiratory syndrome coronavirus 2 acute respiratory distress syndrome. Crit Care Med 2020;48(12):e1332-e1336.
81. Tsolaki V, Zakynthinos GE, Makris D. The ARDSnet protocol may be detrimental in COVID-19. Crit Care 2020;24(1):351.

82. Chiumello D, Camporota L, Gattinoni L, Marini JJ. Complexity and unanswered questions in the pathophysiology of COVID-19 ARDS. Intensive Care Med 2021;47(4):495-496.

83. Bos LDJ, Paulus F, Vlaar APJ, Beenen LFM, Schultz MJ. Subphenotyping acute respiratory distress syndrome in patients with COVID-19: consequences for ventilator management. Ann Am Thorac Soc 2020;17(9):1161-1163.

84. Shi H, Han X, Jiang N, Cao Y, Alwalid O, Gu J, et al. Radiological findings from 81 patients with COVID-19 pneumonia in Wuhan, China: a descriptive study. Lancet Infect Dis 2020;20(4):425-434.

85. Pan Y, Guan H, Zhou S, Wang Y, Li Q, Zhu T, et al. Initial CT findings and temporal changes in patients with the novel coronavirus pneumonia (2019-nCoV): a study of 63 patients in Wuhan, China. Eur Radiol 2020;30(6):3306-3309.

86. Copin MC, Parmentier E, Duburcq T, Poissy J, Mathieu D, Lille COVID-19 ICU and Anatomopathology Group. Time to consider histologic pattern of lung injury to treat critically ill patients with COVID-19 infection. Intensive Care Med 2020;46(6):1124-1126.

87. Mauad T, Duarte-Neto AN, da Silva LFF, de Oliveira EP, de Brito JM, do Nascimento ECT, et al. Tracking the time course of pathological patterns of lung injury in severe COVID-19. Respir Res 2021;22 (1):32.

88. Bösmüller H, Traxler S, Bitzer M, Haberle H, Raiser W, Nann D, et al. The evolution of pulmonary pathology in fatal COVID-19 disease: an autopsy study with clinical correlation. Virchows Arch 2020;477(3):349-357.

89. Oz M, Lorke DE. Multifunctional angiotensin converting enzyme 2, the SARS-CoV-2 entry receptor, and critical appraisal of its role in acute lung injury. Biomed Pharmacother 2021;136:111193.

90. Wang D, Chai XQ, Magnussen CG, Zosky GR, Shu SH, Wei X, et al. Renin-angiotensin-system, a potential pharmacological candidate, in acute respiratory distress syndrome during mechanical ventilation. Pulm Pharmacol Ther 2019;58:101833.

91. Gattinoni L, Marini JJ, Chiumello D, Busana M, Camporota L. COVID-19: scientific reasoning, pragmatism and emotional bias. Ann Intensive Care 2020;10(1):134.

92. Gattinoni L, Marini JJ, Camporota L. The respiratory drive: an overlooked tile of COVID-19 pathophysiology. Am J Respir Crit Care Med 2020;202(8):1079-1080.

93. Cruces P, Retamal J, Hurtado DE, Erranz B, Iturrieta P, González C, et al. A physiological approach to understand the role of respiratory effort in the progression of lung injury in SARS-CoV-2 infection. Crit Care 2020;24(1):494.

94. Dreyfuss D, Soler P, Basset G, Saumon G. High inflation pressure pulmonary edema. Respective effects of high airway pressure, high tidal volume, and positive end-expiratory pressure. Am Rev Respir Dis 1988;137(5):1159-1164.

95. Mascheroni D, Kolobow T, Fumagalli R, Moretti MP, Chen V, Buckhold D. Acute respiratory failure following pharmacologically induced hyperventilation: an experimental animal study. Intensive Care Med 1988;15(1):8-14.

96. Yoshida T, Uchiyama A, Matsuura N, Mashimo T, Fujino Y. Spontaneous breathing during lung-protective ventilation in an experimental acute lung injury model: high transpulmonary pressure associated with strong spontaneous breathing effort may worsen lung injury. Crit Care Med 2012;40(5):1578-1585.

97. Adams AB, Graf J. Does mechanical ventilation "hit" the lungs? Crit Care Med 2008;36(8):2471-2473.

98. Maniatis NA, Kotanidou A, Catravas JD, Orfanos SE. Endothelial pathomechanisms in acute lung injury. Vascul Pharmacol 2008;49:119-133.

99. Hubmayr RD, Kallet RH. Understanding pulmonary stress-strain relationships in severe ARDS and its implications for designing a 


\section{Mechanical Ventilation During the First Year of COVID-19}

safer approach to setting the ventilator. Respir Care 2018;63(2):219226.

100. Amato MB, Meade MO, Slutsky AS, Brochard L, Costa EL, Schoenfeld DA, et al. Driving pressure and survival in the acute respiratory distress syndrome. N Engl J Med 2015;372(8):747-755.

101. Bertoni M, Telias I, Urner M, Long M, Del Sorbo L, Fan E, et al. A novel non-invasive method to detect excessively high respiratory effort and dynamic transpulmonary driving pressure during mechanical ventilation. Crit Care 2019;23(1):346.

102. Kallet RH, Hemphill JC 3rd, Dicker RA, Alonso JA, Campbell AR, Mackersie RC, et al. The spontaneous breathing pattern and work of breathing of patients with acute respiratory distress syndrome and acute lung injury. Respir Care 2007;52(8):989-995.

103. Esnault P, Cardinale M, Hraiech S, Goutorbe P, Baumstrack K, Prud'homme E, et al. High respiratory drive and excessive respiratory efforts predict relapse of respiratory failure in critically ill patients with COVID-19. Am J Respir Crit Care Med 2020;202 (8):1173-1178.

104. Carteaux G, Millán-Guilarte T, De Prost N, Razazi K, Abid S, Thille $\mathrm{AW}$, et al. Failure of noninvasive ventilation for de novo acute hypoxemic respiratory failure: role of tidal volume. Crit Care Med 2016;44 (2):282-290.

105. Richardson S, Hirsch JS, Narasimhan M, Crawford JM, McGinn T, Davidson KW, et al. Presenting characteristics, comorbidities, and outcomes among 5,700 patients hospitalized with COVID-19 in the New York City area. JAMA 2020;323(20):2052-2059.

106. Barbeta E, Motos A, Torres A, Ceccato A, Ferrer M, Cilloniz C, et al. SARS-CoV-2-induced acute respiratory distress syndrome: pulmonary mechanics and gas-exchange abnormalities. Ann Am Thorac Soc 2020;17(9):1164-1168.

107. Ferrando C, Suarez-Sipmann F, Mellado-Artigas R, Hernández M, Gea A, Arruti E, et al. Clinical features, ventilatory management, and outcome of ARDS caused by COVID-19 are similar to other causes of ARDS. Intensive Care Med 2020;46(12):2200-2211.

108. Argenziano MG, Bruce SL, Slater CL, Tiao JR, Baldwin MR, Barr RG, et al. Characterization and clinical course of 1000 patients with coronavirus disease 2019 in New York: retrospective case series. BMJ 2020;369:m1996.

109. Yang SS, Lipes J, Dial S, Schwartz B, Laporta D, Wong E, et al. Outcomes and clinical practice in patients with COVID-19 admitted to the intensive care unit in Montreal, Canada: a descriptive analysis. CMAJ Open 2020;8(4):E788-E795.

110. Schenck EJ, Hoffman K, Goyal P, Choi J, Torres L, Rajwani K, et al. Respiratory mechanics and gas exchange in COVID-19-associated respiratory failure. Ann Am Thorac Soc 2020;17(9):1158-1161.

111. Suleyman G, Fadel RA, Malette KM, Hammond C, Abdulla H, Entz A, et al. Clinical characteristics and morbidity associated with coronavirus disease 2019 in a series of patients in metropolitan Detroit. JAMA Netw Open 2020;3(6):e2012270.

112. Salacup G, Lo KB, Gul F, Peterson E, De Joy R, Bhargav R, et al. Characteristics and clinical outcomes of COVID-19 patients in an underserved-inner city population: a single tertiary center cohort. J Med Virol 2021;93(1):416-423.

113. Mitra AR, Fergusson NA, Lloyd-Smith E, Wormsbecker A, Foster D, Karpov A, et al. Baseline characteristics and outcomes of patients with COVID-19 admitted to intensive care units in Vancouver, Canada: a case series. CMAJ 2020;192(26):E694-E701.

114. Ferguson J, Rosser JI, Quintero O, Scott J, Subramanian A, Gumma $\mathrm{M}$, et al. Characteristics and outcomes of coronavirus disease patients under non-surge conditions, Northern California, USA, March-April 2020. Emerg Infect Dis 2020;26(8):1679-1685.

115. Botta M, Tsonas AM, Pillay J, Boers LS, Algera AG, Bos LDJ, et al. Ventilation management and clinical outcomes in invasively ventilated patients with COVID-19 (PRoVENT-COVID): a national, multicentre, observational cohort study. Lancet Respir Med 2021;9 (2):139-148

116. COVID-ICU Group on behalf of the REVA Network and the COVID-ICU Investigators. Clinical characteristics and day-90 outcomes of 4,244 critically ill adults with COVID-19: a prospective cohort study. Intensive Care Med 2021;47(1):60-73.

117. Regina J, Papadimitriou-Olivgeris M, Burger R, Le Pogam MA, Niemi T, Filippidis P, et al. Epidemiology, risk factors and clinical course of SARS-CoV-2 infected patients in a Swiss university hospital: an observational retrospective study. PLoS One 2020;15(11): e0240781.

118. Israelsen SB, Kristiansen KT, Hindsberger B, Ulrik CS, Andersen O, Jensen M, et al. Characteristics of patients with COVID-19 pneumonia at Hvidovre Hospital, March-April 2020. Dan Med J 2020;67(6): A05200313.

119. Khamis F, Al-Zakwani I, Al Naamani H, Al Lawati S, Pandak N, Ba Omar M, et al. Clinical characteristics and outcomes of the first 63 adult patients hospitalized with COVID-19: an experience from Oman. J Infect Public Health 2020;13:906-913.

120. Hernandez-Romieu AC, Adelman MW, Hockstein MA, Robichaux CJ, Edwards JA, Fazio JC, et al. Timing of intubation and mortality among critically ill coronavirus disease 2019 patients: a single-center cohort study. Crit Care Med 2020;48(11):e1045-e1053.

121. Wang T, Tang C, Chen R, Ruan H, Liang W, Guan W, et al. Clinical features of coronavirus disease 2019 patients with mechanical ventilation: a nationwide study in China. Crit Care Med 2020;48(9):e809e812.

122. Grasselli G, Greco M, Zanella A, Albano G, Antonelli M, Bellani G, et al. Risk factors associated with mortality among patients with COVID-19 in intensive care units in Lombardy, Italy. JAMA Intern Med 2020;180(10):1345-1355.

123. Haase N, Plovsing R, Christensen S, Poulsen LM, Brøchner AC, Rasmussen BS, et al. Characteristics, interventions, and longer term outcomes of COVID-19 ICU patients in Denmark: a nationwide, observational study. Acta Anaesthesiol Scand 2021;65(1):68-75.

124. Almazeedi S, Al-Youha S, Jamal MH, Al-Haddad M, Al-Muhaini A, Al-Ghimlas F, Al-Sabah S. Characteristics, risk factors and outcomes among the first consecutive 1096 patients diagnosed with COVID-19 in Kuwait. EClinicalMedicine 2020;24:100448.

125. Karagiannidis C, Mostert C, Hentschker C, Voshaar T, Malzahn J, Schillinger G. Case characteristics, resource use, and outcomes of 10,021 patients with COVID-19 admitted to 920 German hospitals: an observational study. Lancet Respir Med 2020;8(9):853-862.

126. Giacomelli A, Ridolfo AL, Milazzo L, Oreni L, Bernacchia D, Siano M, et al. 30-day mortality in patients hospitalized with COVID-19 during the first wave of the Italian epidemic: a prospective cohort study. Pharmacol Res 2020;158:104931.

127. Cummings MJ, Baldwin MR, Abrams D, Jacobson SD, Meyer BJ, Balough EM, et al. Epidemiology, clinical course, and outcomes of critically ill adults with COVID-19 in New York City: a prospective cohort study. Lancet 2020;395(10239):1763-1770.

128. Cantini F, Goletti D, Petrone L, Najafi Fard S, Niccoli L, Foti R. Immune therapy, or antiviral therapy, or both for COVID-19: a systematic review. Drugs 2020;80(18):1929-1946.

129. Lim ZJ, Subramaniam A, Ponnapa Reddy M, Blecher G, Kadam U, Afroz A, et al. Case fatality rates for patients with COVID-19 requiring invasive mechanical ventilation: a meta-analysis. Am J Respir Crit Care Med 2021;203(1):54-66.

130. Domecq JP, Lal A, Sheldrick CR, Kumar VK, Boman K, Bolesta S, et al. Outcomes of patients with coronavirus disease 2019 receiving organ support therapies: the international viral infection and respiratory illness universal study registry. Crit Care Med 2021;49(3):437448 . 


\section{Mechanical Ventilation During the First Year of COVID-19}

131. Malek M, Hassanshahi J, Fartootzadeh R, Azizi F, Shahidani S. Nephrogenic acute respiratory distress syndrome: a narrative review on pathophysiology and treatment. Chin J Traumatol 2018;21(1): 4-10.

132. Fowler RA, Lapinsky SE, Hallett D, Detsky AS, Sibbald WJ, Slutsky AS, et al. Critically ill patients with severe acute respiratory syndrome. JAMA 2003;290(3):367-373.

133. Gomersall CD, Joynt GM, Lam P, Li T, Yap F, Lam D, et al. Shortterm outcome of critically ill patients with severe acute respiratory syndrome. Intensive Care Med 2004;30(3):381-387.

134. Al-Dorzi HM, Aldawood AS, Khan R, Baharoon S, Alchin JD, Matroud AA, et al. The critical care response to a hospital outbreak of Middle East respiratory syndrome coronavirus (MERS-CoV) infection: an observational study. Ann Intensive Care 2016;6(1):101.

135. Saad M, Omrani AS, Baig K, Bahloul A, Elzein F, Matin MA, et al. Clinical aspects and outcomes of 70 patients with Middle East respiratory syndrome coronavirus infection: a single-center experience in Saudi Arabia. Int J Infect Dis 2014;29:301-306.

136. Morra ME, Van Thanh L, Kamel MG, Ghazy AA, Altibi AMA, Dat LM, et al. Clinical outcomes of current medical approaches for Middle East respiratory syndrome: a systematic review and metaanalysis. Rev Med Virol 2018;28(3):e1977.

137. Fominskiy EV, Scandroglio AM, Monti G, Calabrò MG, Landoni G, Dell'Acqua A, et al. Prevalence, characteristics, risk factors, and outcomes of invasively ventilated COVID-19 patients with acute kidney injury and renal replacement therapy. Blood Purif 2021;50(1):102109.

138. Villar J, Blanco J, Añón JM, Santos-Bouza A, Blanch L, Ambrós A, et al. The ALIEN study: incidence and outcome of acute respiratory distress syndrome in the era of lung protective ventilation. Intensive Care Med 2011;37(12):1932-1941.

139. Kallet RH, Zhuo H, Yip V, Gomez A, Lipnick MS. Spontaneous breathing trials and conservative sedation practices reduce mechanical ventilation duration in subjects with ARDS. Respir Care 2018;63 (1):1-10.

140. Grasselli G, Zangrillo A, Zanella A, Antonelli M, Cabrini L, Castelli A, et al. Baseline characteristics and outcomes of 1591 patients infected with SARS-CoV-2 admitted to ICUs of the Lombardy Region, Italy. JAMA 2020;323(16):1574-1581.

141. Ziehr DR, Alladina J, Petri CR, Maley JH, Moskowitz A, Medoff $\mathrm{BD}$, et al. Respiratory pathophysiology of mechanically ventilated patients with COVID-19: a cohort study. Am J Respir Crit Care Med 2020;201(12):1560-1564.

142. Zangrillo A, Beretta L, Scandroglio AM, Monti G, Fominskiy E, Colombo S, et al. Characteristics, treatment, outcomes and cause of death of invasively ventilated patients with COVID-19 ARDS in Milan, Italy. Crit Care Resusc 2020;22(3):200-211.

143. Bhatraju PK, Ghassemieh BJ, Nichols M, Kim R, Jerome KR, Nalla AK, et al. Covid-19 in critically ill patients in the Seattle region case series. N Engl J Med 2020;382(21):2012-2022.

144. Rojatta M, Regli IB, Zanforlin A, Ferretti E, Falk M, Strapazzon G, et al. Lung ultrasound and respiratory pathophysiology in mechanically ventilated COVID-19 patients: an observational trial. SN Compr Clin Med 2020 [Epub ahead of print] doi: CrossRef.

145. Sjoding MW, Admon AJ, Saha AK, Kay SG, Brown CA, Co I, et al. Comparing clinical features and outcomes in mechanically ventilated patients with COVID-19 and the acute respiratory distress syndrome. Ann Am Thorac Soc 2021 [Epub ahead of print] doi: CrossRef

146. Haudebourg AF, Perier F, Tuffet S, de Prost N, Razazi K, Mekontso Dessap A, Carteaux G. Respiratory mechanics of COVID-19- versus non-COVID-19-associated acute respiratory distress syndrome. Am J Respir Crit Care Med 2020;202(2):287290.
147. Lenka J, Chhabria MS, Sharma N, Tan BE, Boppana LKT, Venugopal S, et al. Clinical characteristics and outcomes of critically ill patients with COVID-19 in a tertiary community hospital in upstate New York. J Community Hosp Intern Med Perspect 2020;10 (6):491-500.

148. Brault C, Zerbib Y, Kontar L, Fouquet U, Carpentier M, Metzelard $\mathrm{M}$, et al. COVID-19- versus non-COVID-19-related acute respiratory distress syndrome: differences and similarities. Am J Respir Crit Care Med 2020;202(9):1301-1304.

149. Diehl JL, Peron N, Chocron R, Debuc B, Guerot E, Hauw-Berlemont $\mathrm{C}$, et al. Respiratory mechanics and gas exchanges in the early course of COVID-19 ARDS: a hypothesis-generating study. Ann Intensive Care 2020;10(1):95.

150. Vandenbunder B, Ehrmann S, Piagnerelli M, Sauneuf B, Serck N, Soumagne T, et al. Static compliance of the respiratory system in COVID-19 related ARDS: an international multicenter study. Crit Care 2021;25(1):52.

151. Liu X, Liu X, Xu Y, Xu Z, Huang Y, Chen S, et al. Ventilatory ratio in hypercapnic mechanically ventilated patients with COVID-19associated acute respiratory distress syndrome. Am J Respir Crit Care Med 2020;201(10):1297-1299.

152. Kassis ES, Maley JH, Hoenig B, Loo Y, Hayes MM, Moskowitz A, Talmor D. Transpulmonary pressure measurements and lung mechanics in patients with early ARDS and SARS-Co-2. J Crit Care 2021;63:106112 .

153. Beloncle FM, Pavlovsky B, Desprez C, Fage N, Olivier PY, Asfar P, et al. Recruitability and effect of PEEP in SARS-Cov-2-associated acute respiratory distress syndrome. Ann Intensive Care 2020;10 (1):55.

154. Kallet RH. Should PEEP titration be based on chest mechanics in patients with ARDS? Respir Care 2016;61(6):876-890.

155. Arentz M, Yim E, Klaff L, Lokhandwala S, Riedo FX, Chong M, et al. Characteristics and outcomes of 21 critically ill patients with COVID-19 in Washington state. JAMA 2020;323(16):16121614.

156. Network C-IGobotR, the C-ICUI. Clinical characteristics and day-90 outcomes of 4244 critically ill adults with COVID-19: a prospective cohort study. Intensive Care Med 2021;47(1):60-73.

157. Auld SC, Caridi-Scheible M, Blum JM, Robichaux C, Kraft C, Jacob JT, et al. ICU and ventilator mortality among critically ill adults with coronavirus disease 2019. Crit Care Med 2020;48(9): e799-e804.

158. Amato MB, Barbas CS, Medeiros DM, Magaldi RB, Schettino GP, Lorenzi-Filho G, et al. Effect of a protective-ventilation strategy on mortality in the acute respiratory distress syndrome. N Engl J Med 1998;338(6):347-354.

159. Talmor D, Sarge T, Malhotra A, O'Donnell CR, Ritz R, Lisbon A, et al. Mechanical ventilation guided by esophageal pressure in acute lung injury. N Engl J Med 2008;359(20):2095-2104.

160. Kallet RH, Zhuo H, Ho K, Lipnick MS, Gomez A, Matthay MA. Lung injury etiology and other factors influencing the relationship between dead-space fraction and mortality in ARDS. Respir Care 2017;62(10):1241-1248

161. Kallet RH, Katz JA. Respiratory system mechanics in acute respiratory distress syndrome. Respir Care Clin N Am 2003;9 (3):297-319.

162. Kallet RH, Lipnick MS, Burns GD. The nature of recruitment and de-recruitment and its implications for management of ARDS. Respir Care 2021;66(3):510-530.

163. Pan C, Chen L, Lu C, Zhang W, Xia JA, Sklar MC, et al. Lung recruitability in COVID-19-associated acute respiratory distress syndrome: a single-center observational study. Am J Respir Crit Care Med 2020;201(10):1294-1297. 


\section{Mechanical Ventilation During the First Year of COVID-19}

164. Mauri T, Spinelli E, Scotti E, Colussi G, Basile MC, Crotti S, et al. Potential for lung recruitment and ventilation-perfusion mismatch in patients with the acute respiratory distress syndrome from coronavirus disease 2019. Crit Care Med 2020;48(8):11291134.

165. Chen L, Del Sorbo L, Grieco DL, Junhasavasdikul D, Rittayamai N, Soliman I, et al. Potential for lung recruitment estimated by the recruitment-to-inflation ratio in acute respiratory distress syndrome: a clinical trial. Am J Respir Crit Care Med 2020;201 (2):178-187.

166. Antonelli M, Conti G, Moro ML, Esquinas A, Gonzalez-Diaz G, Confalonieri M, et al. Predictors of failure of noninvasive positive pressure ventilation in patients with acute hypoxemic respiratory failure: a multi-center study. Intensive Care Med 2001;27 (11):1718-1728

167. Bellani G, Laffey JG, Pham T, Madotto F, Fan E, Brochard L, et al. Noninvasive ventilation of patients with acute respiratory distress syndrome: insights from the LUNG SAFE study. Am J Respir Crit Care Med 2017;195(1):67-77.

168. Antonelli M, Conti G, Esquinas A, Montini L, Maggiore SM, Bello $\mathrm{G}$, et al. A multiple-center survey on the use in clinical practice of noninvasive ventilation as a first-line intervention for acute respiratory distress syndrome. Crit Care Med 2007;35 (1): $18-25$

169. Chawla R, Mansuriya J, Modi N, Pandey A, Juneja D, Chawla A, et al. Acute respiratory distress syndrome: predictors of noninvasive ventilation failure and intensive care unit mortality in clinical practice. J Crit Care 2016;31(1):26-30.

170. Thille AW, Contou D, Fragnoli C, Córdoba-Izquierdo A, Boissier F, Brun-Buisson C. Non-invasive ventilation for acute hypoxemic respiratory failure: intubation rate and risk factors. Crit Care 2013;17(6): R269.

171. Yoshida Y, Takeda S, Akada S, Hongo T, Tanaka K, Sakamoto A. Factors predicting successful noninvasive ventilation in acute lung injury. J Anesth 2008;22(3):201-206.

172. Sehgal IS, Chaudhuri S, Dhooria S, Agarwal R, Chaudhry D. A study on the role of noninvasive ventilation in mild-to-moderate acute respiratory distress syndrome. Indian J Crit Care Med 2015;19(10):593599.

173. Suttapanit K, Boriboon J, Sanguanwit P. Risk factors for non-invasive ventilation failure in influenza infection with acute respiratory failure in emergency department. Am J Emerg Med 2020;38 (9):1901-1907.

174. Cheung TM, Yam LY, So LK, Lau AC, Poon E, Kong BM, et al. Effectiveness of noninvasive positive pressure ventilation in the treatment of acute respiratory failure in severe acute respiratory syndrome. Chest 2004;126(3):845-850.

175. Han F, Jiang YY, Zheng JH, Gao ZC, He QY. Noninvasive positive pressure ventilation treatment for acute respiratory failure in SARS. Sleep Breath 2004;8(2):97-106.

176. Yam LY, Chen RC, Zhong NS. SARS: ventilatory and intensive care. Respirology 2003;8 Suppl(Suppl 1):S31-S35

177. Masclans JR, Perez M, Almirall J, Lorente L, Marqués A, Socias L, et al. Early non-invasive ventilation treatment for severe influenza pneumonia. Clin Microbiol Infect 2013;19 (3):249-256

178. Rello J, Rodríguez A, Ibañez P, Socias L, Cebrian J, Marques A, et al. Intensive care adult patients with severe respiratory failure caused by influenza A (H1N1)v in Spain. Crit Care 2009;13(5): R148.

179. Kumar A, Zarychanski R, Pinto R, Cook DJ, Marshall J, Lacroix J, et al. Critically ill patients with 2009 influenza A(H1N1) infection in Canada. JAMA 2009;302(17):1872-1879.
180. Domínguez-Cherit G, Lapinsky SE, Macias AE, Pinto R, Espinosa-Perez L, de la Torre A, et al. Critically Ill patients with 2009 influenza A(H1N1) in Mexico. JAMA 2009;302(17):18801887.

181. Alraddadi BQ, Al-Hameed FM, Mandourah Y, Almekhlafi GA, Jose $\mathrm{J}$, Al-Omari A, et al. Noninvasive ventilation in critically ill patients with the Middle East respiratory syndrome. Influenza Other Respir Viruses 2019;13:382-390.

182. Oranger M, Gonzalez-Bermejo J, Dacosta-Noble P, Llontop C, Guerder A, Trosini-Desert V, et al. Continuous positive airway pressure to avoid intubation in SARS-CoV-2 pneumonia: a twoperiod retrospective case-control study. Eur Respir J 2020;56 (2):2001692.

183. Brusasco C, Corradi F, Di Domenico A, Raggi F, Timossi G, Santori $\mathrm{G}$, et al. Continuous positive airway pressure in COVID-19 patients with moderate-to-severe respiratory failure. Eur Respir J 2021;57 (2):2002524

184. Sivaloganathan AA, Nasim-Mohi M, Brown MM, Abdul N, Jackson A, Fletcher SV, et al. Noninvasive ventilation for COVID-19-associated acute hypoxaemic respiratory failure: experience from a single centre. Br J Anaesth 2020;125(4):e368-e371.

185. Avdeev SN, Yaroshetskiy AI, Tsareva NA, Merzhoeva ZM, Trushenko NV, Nekludova GV, et al. Noninvasive ventilation for acute hypoxemic respiratory failure in patients with COVID-19. Am J Emerg Med 2021;39:154-157.

186. Aliberti S, Radovanovic D, Billi F, Sotgiu G, Costanzo M, Pilocane $\mathrm{T}$, et al. Helmet CPAP treatment in patients with COVID-19 pneumonia: a multicentre cohort study. Eur Respir J 2020;56(4):2001935.

187. Gaulton TG, Bellani G, Foti G, Frazer MJ, Fuchs BD, Cereda M. Early clinical experience in using helmet continuous positive airway pressure and high-flow nasal cannula in overweight and obese patients with acute hypoxemic respiratory failure from coronavirus disease 2019. Crit Care Explor 2020;2(9):e0216.

188. Bellani G, Grasselli G, Cecconi M, Antolini L, Borelli M, De Giacomi F, et al. Noninvasive ventilatory support of COVID-19 patients outside the intensive care units (ward-COVID). Ann Am Thorac Soc 2021 [Epub ahead of print] doi: CrossRef

189. Coppadoro A, Benini A, Fruscio R, Verga L, Mazzola P, Bellelli G, et al. Helmet CPAP to treat hypoxic pneumonia outside the ICU: an observational study during the COVID-19 outbreak. Crit Care 2021;25 (1):80.

190. Grieco DL, Menga LS, Cesarano M, Rosà T, Spadaro S, Bitondo MM, et al. Effect of helmet noninvasive ventilation vs high-flow nasal oxygen on days free of respiratory support in patients with COVID-19 and moderate to severe hypoxemic respiratory failure: the HENIVOT randomized clinical trial. JAMA 2021;325(17):1731-1743.

191. Baqi S, Naz A, Sayeed MA, Khan S, Ismail H, Kumar V, et al. Clinical characteristics and outcome of patients with severe COVID19 pneumonia at a public sector hospital in Karachi, Pakistan. Cureus 2021;13(2):e13107.

192. Menzella F, Barbieri C, Fontana M, Scelfo C, Castagnetti C, Ghidoni $\mathrm{G}$, et al. Effectiveness of noninvasive ventilation in COVID-19 related-acute respiratory distress syndrome. Clin Respir J 2021 [Epub ahead of print] doi: DOI:CrossRef.

193. Franco C, Facciolongo N, Tonelli R, Dongilli R, Vianello A, Pisani $\mathrm{L}$, et al. Feasibility and clinical impact of out-of-ICU noninvasive respiratory support in patients with COVID-19-related pneumonia. Eur Respir J 2020;56(5):2002130.

194. Di Domenico S, Coen D, Bergamaschi M, Albertini V, Ghezzi L, Cazzaniga MM, et al. Clinical characteristics and respiratory support of 310 COVID-19 patients, diagnosed at the emergency room: a single-center retrospective study. Intern Emerg Med 2020 [Epub ahead of print]. 


\section{Mechanical Ventilation During the First Year of COVID-19}

195. Kurtz P, Bastos LSL, Dantas LF, Zampieri FG, Soares M, Hamacher $\mathrm{S}$, et al. Evolving changes in mortality of 13,301 critically ill adult patients with COVID-19 over 8 months. Intensive Care Med 2021 [Epub ahead of print].

196. Lee N, Hui D, Wu A, Chan P, Cameron P, Joynt GM, et al. A major outbreak of severe acute respiratory syndrome in Hong Kong. N Engl J Med 2003;348(20):1986-1994.

197. Booth CM, Matukas LM, Tomlinson GA, Rachlis AR, Rose DB, Dwosh HA, et al. Clinical features and short-term outcomes of 144 patients with SARS in the greater Toronto area. JAMA 2003;289 (21):2801-2809.
198. Lew TWK, Kwek TK, Tai D, Earnest A, Loo S, Singh K, et al. Acute respiratory distress syndrome in critically ill patients with severe acute respiratory syndrome. JAMA 2003;290(3):374-380.

199. Murray JF, Matthay MA, Luce JM, Flick MR. An expanded definition of the adult respiratory distress syndrome. Am Rev Respir Dis 1988;138(3):720-723.

200. Bernard GR, Artigas A, Brigham KL, Carlet J, Falke K, Hudson $\mathrm{L}$, et al. The American-European Consensus Conference on ARDS. Definitions, mechanisms, relevant outcomes, and clinical trial coordination. Am J Respir Crit Care Med 1994; 149(3 Pt 1):818-824. 